\title{
Fiscal devaluation and relative prices: evidence from the Euro area
}

\author{
Giampaolo Arachi ${ }^{1} \cdot$ Debora Assisi $^{1}$ (D)
}

Published online: 19 August 2020

(C) The Author(s) 2020

\begin{abstract}
The theoretical literature has long recognized that a fiscal devaluation, brought about by a budget-neutral shift from social security contributions towards value added tax (V-FD), could improve price competitiveness and help restore trade imbalances, especially for countries that cannot devaluate their currency. This paper provides evidence on the effects of a fiscal devaluation on the real effective exchange rate, the terms of trade and net exports. We focus on countries that joined the Euro Area in 1999 for which fiscal devaluation is a salient issue. We find that the responses are highly heterogeneous across countries and, on average, the estimates provide only a weak support to the theoretical predictions that a fiscal devaluation could affect the real effective exchange rate and the terms of trade. Consistently, we also find negligible results on the trade balance. We conclude that the potential of a V-FD should not be overemphasized, since its effects are rather limited on both relative prices and quantities.
\end{abstract}

Keywords Fiscal devaluation $\cdot$ Exchange rate $\cdot$ Terms of trade $\cdot$ Internal competitiveness

JEL Classification $\mathrm{E} 62 \cdot \mathrm{F} 45 \cdot \mathrm{H} 87$

\section{Introduction}

Until the outbreak of the global financial crisis, countries that join the Euro Area (EA) have shown diverging trends in competitiveness which have fostered the growth of large current account imbalances, with Northern European countries

Debora Assisi

debora.assisi@unisalento.it

Giampaolo Arachi

giampaolo.arachi@unisalento.it

1 Dipartimento di Scienze dell'Economia, Università del Salento, Via per Monteroni, 73100 Lecce, Italy 
accumulating surpluses, and Southern countries experiencing current account deficits. In subsequent years, given that a nominal unilateral devaluation was unfeasible within a monetary union, the reduction of external deficits was primarily achieved through internal devaluations which have entailed large economic and social costs (Stockhammer and Sotiropoulos 2014). These experiences have fostered a debate on whether the costs of the adjustment could be reduced by using taxes as a tool to manipulate international relative prices.

The literature has long recognized that the real effects of a nominal depreciation may be indirectly achieved, under sticky prices, through a series of revenue-neutral tax shifts which are usually referred to as "fiscal" devaluations. Keynes (1931) first argued that the combination of an import tariff and an export subsidy could lead to a rise in the domestic price of importable and to a reduction in the foreign price of exportable goods. Later, Calmfors $(1993,1998)$ showed that a reduction in labour taxes matched by changes in other taxes (mainly consumption taxes) could replicate the real allocations of output and employment reached under a nominal exchange rate devaluation.

The policy debate in Europe has focused in particular on fiscal devaluation realized through a reduction in employers' social security contributions (SSCs) compensated by an increase in the value added tax (VAT). When VAT is levied according to the destination principle, exports are zero-rated. Hence, changes in VAT will only affect the prices of both domestically produced and imported goods. With fixed nominal wages, a cut in SSCs would lead to a reduction in labour costs. To the extent that domestic firms will pass these lower costs onto the consumers in the form of lower prices, the proposed tax shift would increase the relative price of imported goods. The decline in the relative price of domestic-produced goods may thus help to improve the trade balance that would also lead to an output growth. This policy has been suggested by the Commission in many recommendations to Member States in the context of the European Semester. The European debate has also been echoed in the debate on the so-called "destination-based cash flow tax" (DBCFT) in the USA. In fact, as argued by Auerbach et al. (2017), a DBCFT would bring about the same economic effects as a rise in the VAT coupled with a reduction in taxes on wages and salaries.

Recent literature has focused on VAT-based fiscal devaluation (V-FD) mainly through theoretical analyses. Farhi et al. (2014) have formally analysed the detailed conditions under which a tax shift from SSCs to VAT may exactly replicate the allocations reached under a nominal depreciation. In particular, the authors show that a fiscal devaluation may mimic the effects of a nominal devaluation by producing the same depreciation of the terms of trade (TOT) and the real effective exchange rate (REER) when prices are set in the producer's currency.

Other studies have simulated the impact of fiscal devaluation on growth or trade through general equilibrium models. They suggest that tax shifts from labour to consumption should lead to an output and trade balance improvement, at least in the short run. The positive effect on net exports is however small in magnitude, ranging from 0.3 to 0.6 per cent of GDP, and vanishes some periods after the shock (Annicchiarico et al. 2015; Gomes et al. 2016; Engler et al. 2017). In the long run, in fact, the adjustment in real wages would absorb the reduction in labour costs originally 
caused by the policy, with a subsequent erosion of the country's competitive trade advantage. The positive effect on the trade balance is due to depreciation in relative prices. Engler et al. (2017), for instance, find that a fiscal devaluation of 1 per cent of GDP, carried out in Southern European countries, depreciates the REER by 0.3 per cent and deteriorates the TOT by 0.7 per cent, leading to a fairly limited impact on the trade balance, which improves by 0.3 per cent of GDP.

Very few papers have sought to provide empirical evidence on the economic effects of fiscal devaluation. De Mooij and Keen (2013) estimate an error correction model for a panel of OECD countries allowing responses to differ according to the exchange rate regime. In particular, for EA countries they find that a shift of 1 per cent of GDP from SSCs to VAT would improve the trade balance by 3.4 per cent of GDP in the short run. Their analysis, however, does not properly account for the possibility of simultaneous tax changes across countries. Holzner et al. (2018) have accounted for the latter issue by focusing on a panel of European Union countries. They find a somewhat smaller effect on the trade balance compared to De Mooij and Keen (2013). Moreover, they argue that the magnitude of the impact varies significantly across countries, suggesting that an accurate analysis on fiscal devaluations should properly account for heterogeneity. Both studies fail to shed light on the channels through which a fiscal devaluation affects the trade balance. Theory suggests that a fiscal devaluation will exert its effects by affecting the TOT and the REER. However, even if an extensive literature has investigated the economic determinants of both the TOT and the REER (Corsetti et al. 2007; Monacelli and Perotti 2008; Galstyan and Lane 2009; Griffoli et al. 2015), only a few papers have focused on the relationship between specific taxes and relative prices (Alesina and Perotti 1995; Freund and Gagnon 2017), and little is known on the potential impact of a fiscal devaluation. Tkalec et al. (2019) studied the impact of both VAT and SSCs' tax changes on the real exchange rate, but do not specifically analyse a revenue-neutral tax shift. To the best of our knowledge, no paper has ever analysed the effects of a fiscal devaluation on the relative price of tradables (TOT), though this should perhaps be more important since theory suggests that the trade balance should mainly be affected by the reduction in the relative price of domestic tradable goods.

This paper aims at bridging the gap between the literature on fiscal devaluation and the literature on the determinants of international relative prices by providing the first empirical evidence on the effects of a revenue-neutral tax shift from SSCs to VAT on both the TOT and the REER. Moreover, in the second part we complement the analysis by estimating the impact of fiscal devaluation on the trade balance. We estimate the effects of the tax shift by considering both unilateral and simultaneous tax reforms and focus on the EA to evaluate the potential of fiscal devaluations for countries that cannot devalue their currencies.

The literature has proposed various approaches for measuring variations in the effective tax burden. To allow comparability with previous studies, we consider three alternative proxies: tax to GDP ratios, tax ratios or implicit tax rates.

As far as the econometric model is concerned, the literature suggests that the effects may substantially reverse in the long term. To distinguish between the short- and the long-run responses we rely on an error correction model. We also try to overcome two weaknesses in the existing literature. First, we do not restrict 
coefficients to being homogeneous across countries and estimate a mean group model. Moreover, we control for the cross-sectional dependence that could arise because of unobservable common shocks. This issue may be particularly salient in our setting since, in the period considered, the EA countries were hit by several common shocks, such as the 2008 global financial and the 2011 sovereign debt crisis. If not properly accounted for, such a correlation may lead to biased estimates (Pesaran 2006; Pesaran and Tosetti 2011). For this reason, we rely on the Pesaran (2006) common correlated effects estimator adjusted to a dynamic setting following Chudik and Pesaran (2015).

We find that when simultaneous tax reforms are taken into consideration, a V-FD depreciates both the REER and the TOT in the short run as predicted by the theory under producer currency pricing. However, the effects are rather limited in size and only weakly statistically significant. The limited impact of the fiscal depreciation on prices is also reflected on quantity adjustment, as the change in net exports (albeit positive) is not statistically significant. In the long run, the effects vanish on both relative prices and net exports, corroborating previous studies showing that the impact of a V-FD tends to reverse in the longer run. The results are somewhat puzzling when we focus on unilateral fiscal devaluations, where, in the short run, we find a weak appreciation of the relative prices but a significant increase in the trade balance. Our analysis also shows that the effects of a V-FD are highly heterogeneous across countries, probably due to country-specific characteristics. This suggests that the results of past analyses, which impose the constraint of homogeneous coefficients, may be biased. In fact, we find that the impact on net exports is stronger when the coefficients are assumed homogeneous. Overall, our results suggest that even if the V-FD could affect relative price and quantities as suggested by the theory, its potential as a policy tool to correct current account imbalances should not be overstated.

The remainder is organized as follows. Section 2 provides a review of existing findings. Section 3 outlines the empirical strategy and the econometric specification, while Sect. 4 describes the data. Section 5 reports the results and Sect. 6 concludes with some closing remarks.

\section{Related findings}

The literature has highlighted several channels through which domestic taxes may affect the nominal exchange rate, the capital account and the trade balance (Alworth and Arachi 2010). Two policies in particular have been proposed as a means to replicate the positive effects on a country's trade balance reached under a nominal devaluation. The first one, originally suggested by Keynes (1931), is given by an ad-valorem tariff on all imports coupled with a uniform subsidy on all exports. The second one, on which we focus in this paper, is based on a cut in payroll taxes compensated by an increase in the tax burden on workers and households. Calmfors $(1993,1998)$ first argued that a cut in payroll taxes, keeping the fiscal balance unchanged, would have the same short-run effects on output 
and employment as a nominal exchange rate devaluation, in a static model with a fixed capital stock and nominal wage rigidity.

The similarity between nominal and fiscal devaluations is clearest when the revenue loss of a reduction in social contributions paid by employers is compensated by an increase in VAT. For a fixed money wage, a cut in payroll taxes lowers the labour cost relative to foreign prices measured in domestic currency in the same way as a nominal exchange rate devaluation. To the extent that lower labour costs are reflected in lower prices for domestically produced commodities, the tax shift from payroll taxes to VAT will leave the purchasing power in terms of domestic goods unaffected while the import prices will increase. As in the case of a nominal devaluation, employees will then experience a loss of purchasing power in terms of imports that will facilitate a trade balance improvement in the short run.

The consequences of a V-FD have been analysed also through simulation methods, both from a single-country perspective (Annicchiarico et al. 2015; Gomes et al. 2016) and in a multi-country setting (Engler et al. 2017, 2018). The results of existing studies suggest that a fiscal devaluation leads to a relative price depreciation and to a rise in net exports, especially for the trade deficit countries, at least in the short run.

On the empirical side, some papers have documented a correlation between taxes and trade (Lane and Perotti 1998, 2003; Keen and Syed 2006) but very few have tried to directly assess the effects of a shift from SSC to VAT on trade performance. One of the earliest works in this direction is Alworth and Arachi (2010) which finds that net exports of OECD countries are not significantly affected by VAT, while SSCs have a negative effect (albeit weakly significant) for EA countries after the introduction of the euro. The most relevant contribution in the empirical analysis on the economic effects of a fiscal devaluation is by De Mooij and Keen (2013). They estimate an error correction model for a panel of thirty OECD countries between 1965 and 2009. They show that when estimated coefficients on VAT and SSCs are combined to gauge the impact of a revenueneutral tax shift of 1 per cent of GDP in the EA, net exports increase by 3.44 per cent in the short run. One of the main drawbacks of the analysis by De Mooij and Keen (2013) is that they do not specifically distinguish between unilateral and simultaneous tax policies. The possibility of simultaneous fiscal devaluations is taken into account by Holzner et al. (2018), who also highlight how the impact of the tax policy strongly depends on country-specific factors, such as differences in the trade openness.

By focusing merely on quantities, existing studies shed no light on the channels through which fiscal devaluations may affect net exports. The basic idea underlying fiscal devaluation is that it could mimic the effects of an exchange rate depreciation. A nominal devaluation affects the trade balance in an economy by changing the two main international relative prices: the TOT and the consumer-price REER.

The TOT is defined as the ratio of the export price index $\left(P_{X}\right)$ to the import price index $\left(P_{M}^{*}\right)$ (inclusive of VAT): 


$$
\mathrm{TOT}=\frac{P_{X}\left(1-\tau_{v}\right)}{P_{M}^{*}} \varepsilon,
$$

where an asterisk denotes variables in foreign currency, $\tau_{v}$ the VAT rate and $\varepsilon$ is the nominal exchange rate, defined as the price of one unit of home currency in terms of units of the foreign currency (hence an increase in $\varepsilon$ represents a home currency appreciation). The REER is defined as the ratio of the foreign $\left(P^{*}\right)$ and the domestic $(P)$ price index:

$$
\mathrm{REER}=\frac{P}{P^{*} \varepsilon}
$$

These relative prices affect two key equilibrium allocations: the TOT shapes the trade balance in a country budget constraint while the REER influences the equilibrium in the world asset market by affecting savings and portfolio choices.

The sign of the short-run impact on the TOT will, in particular, depend on whether firms set the same price in the producer currency in the domestic and the foreign market (producer currency pricing) or if they set both a home market price in home currency and foreign market price in the foreign currency (local currency pricing).

Under flexible exchange rates, if prices are set in the producer currency-and thus when domestic import prices are sticky in terms of foreign currency-a nominal depreciation will cause a proportional rise in import prices. At the same time, since domestic export prices are sticky in domestic currency, export prices will proportionally fall. Thus, under the producer currency pricing assumption a nominal depreciation of the exchange rate will automatically reduce the TOT, shifting domestic demand towards domestically produced tradables.

When exporters' prices are quoted in the buyers' currency and are rigid in terms of those currencies (local currency pricing), the exchange rate passthrough to import prices is instead zero. The foreign price of imports always equals the exchange rate adjusted price applied in the domestic market, so that $P_{M}^{*}=\varepsilon \times P_{M}, P_{X}^{*}=\varepsilon \times P_{X}$, and TOT $=P_{X}^{*}\left(1-\tau_{v}\right) / \varepsilon \times P_{M}$. Since all prices are temporarily fixed in domestic currency units, when the nominal exchange rate changes, neither domestic nor foreign consumers perceive any change in the relative price of exports and other domestically available goods. This in practice means that, given unchanged prices of exports and imports, when a country depreciates its currency the TOT increases (Obstfeld and Rogoff 2000).

Summarizing, when prices are set in the producer currency a devaluation of the nominal exchange rate should lead to an expenditure-switching effect since export prices of the devaluing country should fall, with an ensuing redirection of world expenditure in favour of its products in the short run. This is the basic mechanism under which a nominal devaluation may help to improve the trade balance.

Farhi et al. (2014) is one of the earlier papers explaining the detailed conditions under which a VAT increase coupled with a uniform payroll tax reduction can replicate the movements in the TOT and the REER brought about a nominal devaluation. In their benchmark model, they assume nominal wage rigidity and 
fixed exchange rate. Given the nature of price rigidity, the price setting-whether prices are set under producer currency or in the local currency-plays a central role for the determination of the real effects of a devaluation. Moreover, the expected or unexpected nature of fiscal devaluations is fundamental for understanding the exact details of which instruments need to be used.

In particular, the above-mentioned authors show that a revenue-neutral shift from payroll taxes to VAT generates the same movements in the TOT as a nominal devaluation, independently of the expected or unexpected nature of the policy. An increase in VAT coupled with a reduction in the payroll tax would leave unchanged the wedge in the home price setting. Under producer currency pricing, the increase in the VAT rate will reduce the relative price of home exports to home imports as the tax is levied on home consumers of foreign goods and reimbursed to home exporters (who can then charge a lower price in the foreign market). Under local currency pricing, in contrast, the tax shift leads to a short-run appreciation of the TOT (Farhi et al. 2014).

The equivalence between a revenue-neutral shift from payroll taxes to VAT and a nominal exchange rate devaluation does not always hold with respect to the REER. The REER depreciates following a nominal devaluation, whereas it appreciates following a tax shift towards VAT as the home price level increases with respect to the foreign one. It follows that a fiscal devaluation implemented through a revenueneutral tax shift from payroll taxes to VAT can exactly replicate the real effects of a nominal devaluation only when the dynamics of the REER do not affect equilibrium allocations. This is the case when the devaluation is unexpected and asset markets are incomplete since under these circumstances a one-time unanticipated jump in the REER would affect neither savings nor portfolio decisions. When asset markets are complete and the policy change is anticipated, savings and portfolio decisions would be differentially affected by the tax shift due to the foreseen appreciation of the REER. In this case, in order to replicate a nominal exchange rate devaluation, the shift from payroll taxes to VAT should be complemented with the introduction of a consumption subsidy coupled with a proportional increase of the labour tax. The consumption subsidy offsets the relative increase in the home price level, but it would distort the wage setting and labour supply decisions. The latter distortion could be undone by a proportional labour income tax. ${ }^{1}$

More recently, Erceg et al. (2018) call into question the equivalence results in Farhi et al. (2014), arguing that these are sensitive to the assumption that consumer prices are sticky inclusive of VAT. They show that with fixed exchange rates when consumer prices are sticky in pre-tax terms, a fiscal devaluation in the form of VAT tax-payroll subsidy will lead to an increase in consumer prices of the domestic good

\footnotetext{
1 The equivalence between a nominal and a fiscal devaluation also depends on the currency denomination of debt. In the case of incomplete asset markets with home currency denominated international bonds, a VAT-based fiscal devaluation needs to be complemented with a partial default on foreign holder bonds denominated in domestic currency (Farhi et al. 2014).
} 
in the home market, which would limit any depreciation of the TOT and further enhance the REER appreciation, thus leading to contractionary effects.

In any case, as most of the existing results outline, the effects of a fiscal devaluation are likely to be quite small; moreover, they are deemed to be temporary as they should vanish once prices adjust and in the long-run both TOT and REER will return to their pre-devaluation level.

Empirically little is known on both the actual impact of taxes on international relative prices and on the ensuing effects on imports and exports. ${ }^{2}$ Recently, Tkalec et al. (2019) have analysed the effects of VAT and SSC on the bilateral real exchange rate measured by using either unit labour costs or consumer-price index. They estimate an error correction model assuming that both the short- and the long-run coefficients are homogenous across countries, thus disregarding the possibility of heterogeneous effects and the possible presence of common unobserved shocks. Moreover, focusing only on real exchange rates, they ignore the effects on the relative price of tradables.

In the next section, we report the empirical strategy adopted for the assessment of the real effects of a fiscal devaluation. Our analysis specifically takes into account the possibility of simultaneous tax policies across countries, heterogeneous dynamics and common unobserved shocks.

\section{Empirical strategy and model specification}

The estimation strategy should cope with a series of issues particularly salient in our framework. First, the assessment of macroeconomic implications of tax policies requires a special focus on the measurement of exogenous variations in the tax system. Exogenous tax changes could be simply measured by using statutory tax rates. However, statutory rates fail to capture changes in the effective tax burden due to reforms of various elements of the tax base (e.g. tax exemptions, deductions and credits).

Some authors rely on aggregate measures of the average tax burden, such as the revenue to GDP ratio (Bleaney et al. 2001; De Mooij and Keen 2013), or tax ratios calculated as the share of one type of tax in total revenue (Arnold et al. 2011; Xing 2012). The main advantage of these measures is that the revenue raised by a specific tax instrument is a summary measure of the broader range of complex features related to its rate and base. Moreover, the use of these tax measures enables estimation of the impact of shifts between revenue sources that leave total revenue unchanged. On the other hand, these measures are likely to be endogenous at least in the long run (Arachi et al. 2015).

To overcome endogeneity concerns related to tax ratios, other measures have been suggested by the literature. Mendoza et al. (1994) proposed computing macro-level

\footnotetext{
${ }^{2}$ Kangur (2018) surveys the recent literature that has estimated the impact of international relative prices on export developments and finds that the results are sensitive to the indicator used to measure competitiveness and to the country investigated.
} 
effective tax rates, also named 'implicit tax rates' by the European Commission (2013). The implicit tax rates are defined by dividing the revenue from one type of tax by the corresponding tax base, the latter estimated using national accounts data. As shown by Arachi et al. (2015) implicit tax rates are less directly affected by the development in factor shares. Furthermore, implicit tax rates are consistent with theoretical models since they represent the wedges distorting optimizing plans in a macroeconomic representative agent setting.

To allow a ready comparison with the previous literature we perform our analysis using alternatively tax to GDP ratios, tax ratios and implicit tax rates. We focus on fiscal devaluation realized through a shift from employers' SSCs to VAT for a given level of revenue. A tax reform of this kind would increase the wedge due to VAT and reduce (by the same amount) the SSCs' wedge leaving unchanged the ratio between total revenue and GDP.

As regards the empirical model specification, it is important to distinguish between the short- and the long-run effects. A fiscal devaluation may affect international relative prices and trade balance in the short run with sticky prices, whereas the effects could vanish in the long period because of the price adjustment (De Mooij and Keen, 2013).

As a preliminary step of the analysis we test for non-stationarity of the set of explanatory variables included in the empirical model. Table 1 shows the statistics from three alternative panel unit root tests. The first column reports the results from the Im et al. (2003) (IPS) test, under the null hypothesis that all panels contain a unit root. We then report the Maddala and Wu (1999) statistic, which tests the null that the series are integrated of order 1 under the assumption of cross-sectional independence. Since we cannot exclude the presence of cross-sectional dependence across the units in the panel, we perform a unit root test that takes this feature into account. We thus check for nonstationarity in the series using a second-generation test proposed by Pesaran (2007): the cross-sectional augmented panel unit root test (CIPS), designed for analysis of unit root in heterogeneous panel setups with cross-sectional dependence.

In Table 1, we report p-values from the tests performed on both, the variables in levels and first differences.

Overall, the tests do not reject the null hypothesis of unit root for (most of) the variables in levels, whereas, when we perform the tests on first differences, we can conclude for stationarity. Hence, since the results of the test point to a possible cointegration, we model the long- and the short-run dynamics using an Error Correction Model (ECM) in the form:

$$
\Delta P_{i, t}=-\varphi_{i}\left(P_{i t-1}-\sum_{v} \beta_{i}^{v} X_{i t}^{v}-\sum_{m} \beta_{i}^{m} F_{i t}^{m}\right)+\sum_{v} b_{i}^{v} \Delta X_{i t}^{v}+\sum_{m} b_{i}^{m} \Delta F_{i t}^{m}+z_{t}+\delta_{i}+\varepsilon_{i, t},
$$

where the $i$ and $t$ indexes represent, respectively, country and time. $P_{i, t}$ represents alternately the two international relative prices analysed in this paper. $X_{i t}^{v}$ and $F_{i t}^{m}$ represent, respectively, the vector of non-fiscal and fiscal variables which are assumed to affect relative prices. The vector of non-fiscal determinants $X_{i t}^{v}$ includes productivity and the interest rate. In particular, productivity is the labour productivity differential (between tradable and nontradable sector), computed as the gross 
Table 1 Panel unit root tests

\begin{tabular}{|c|c|c|c|c|c|c|}
\hline \multirow[t]{2}{*}{ Variables } & \multicolumn{2}{|c|}{ Im et al. (2003) W-t-bar } & \multicolumn{2}{|c|}{$\begin{array}{l}\text { Maddala and Wu (1999) } \\
\text { Chi-sq }\end{array}$} & \multicolumn{2}{|c|}{ Pesaran (2007) Zt-bar } \\
\hline & Level & First diff. & Level & First diff. & Level & First diff. \\
\hline REER & 0.2274 & 0.0000 & 0.947 & 0.0000 & 0.352 & 0.0000 \\
\hline TOT & 0.0524 & 0.0000 & 0.389 & 0.0000 & 0.343 & 0.0000 \\
\hline $\mathrm{Y}$ & 0.9941 & 0.0000 & 0.740 & 0.0000 & 0.530 & 0.0000 \\
\hline I & 0.7815 & 0.0000 & 0.242 & 0.0000 & 0.181 & 0.0000 \\
\hline G & 0.2628 & 0.0000 & 0.342 & 0.0000 & 0.982 & 0.0000 \\
\hline $\mathrm{T}$ & 0.1888 & 0.0000 & 0.368 & 0.0000 & 0.300 & 0.0000 \\
\hline NX & 0.1765 & 0.0000 & 0.152 & 0.0000 & 0.385 & 0.0000 \\
\hline GDP & 0.0004 & 0.0100 & 0.001 & 0.0000 & 0.038 & 0.0000 \\
\hline DEP & 0.4089 & 0.005 & 0.129 & 0.005 & 0.999 & 0.002 \\
\hline UR & 0.0000 & 0.0000 & 0.004 & 0.0000 & 0.926 & 0.004 \\
\hline GGbal & 0.3966 & 0.0000 & 0.487 & 0.0000 & 0.055 & 0.0000 \\
\hline REV & 0.3483 & 0.0000 & 0.559 & 0.0000 & 0.539 & 0.0000 \\
\hline $\mathrm{VAT}_{\text {GDP }}$ & 0.1152 & 0.0000 & 0.335 & 0.0000 & 0.818 & 0.0000 \\
\hline $\mathrm{SSC}_{\mathrm{GDP}}$ & 0.1322 & 0.0000 & 0.937 & 0.0000 & 0.365 & 0.0000 \\
\hline $\mathrm{VAT}_{\mathrm{GDP}(\mathbf{T P})}$ & 0.1578 & 0.0000 & 0.411 & 0.0000 & 0.142 & 0.0000 \\
\hline $\mathrm{SSC}_{\mathrm{GDP}(\mathrm{TP})}$ & 0.0280 & 0.0000 & 0.134 & 0.0000 & 0.204 & 0.0000 \\
\hline $\mathrm{VAT}_{\mathrm{TR}}$ & 0.3073 & 0.0000 & 0.465 & 0.0000 & 0.742 & 0.0000 \\
\hline $\mathrm{SSC}_{\mathrm{TR}}$ & 0.2809 & 0.0000 & 0.636 & 0.0000 & 0.685 & 0.0000 \\
\hline $\mathrm{VAT}_{\mathrm{TR}(\mathrm{TP})}$ & 0.0003 & 0.0000 & 0.003 & 0.0000 & 0.907 & 0.0000 \\
\hline $\mathrm{SSC}_{\mathrm{TR}(\mathrm{TP})}$ & 0.2264 & 0.0000 & 0.405 & 0.0000 & 0.809 & 0.0000 \\
\hline VAT $_{\text {ITR }}$ & 0.3283 & 0.0000 & 0.650 & 0.0000 & 0.817 & 0.0000 \\
\hline $\mathrm{SSC}_{\mathrm{ITR}}$ & 0.5785 & 0.0000 & 0.499 & 0.0000 & 0.200 & 0.0000 \\
\hline $\mathrm{VAT}_{\mathrm{ITR}(\mathrm{TP})}$ & 0.9731 & 0.0000 & 0.996 & 0.0000 & 0.259 & 0.0000 \\
\hline $\mathrm{SSC}_{\mathrm{ITR}(\mathrm{TP})}$ & 0.0811 & 0.0000 & 0.207 & 0.0000 & 0.363 & 0.0000 \\
\hline $\mathrm{VAT}_{\text {ITR }} / \mathrm{L}$ & 0.2588 & 0.0000 & 0.239 & 0.0000 & 0.599 & 0.0000 \\
\hline $\mathrm{VAT}_{\mathrm{ITR}} / \mathrm{L}_{(\mathrm{TP})}$ & 0.0000 & 0.0000 & 0.000 & 0.0000 & 0.997 & 0.0000 \\
\hline $\mathrm{SSC}_{\mathrm{ITR}} / \mathrm{C}$ & 0.1607 & 0.0000 & 0.044 & 0.0000 & 0.717 & 0.0000 \\
\hline $\mathrm{SSC}_{\mathrm{ITR}} / \mathrm{C}_{(\mathrm{TP})}$ & 0.4358 & 0.0000 & 0.568 & 0.0000 & 0.189 & 0.0000 \\
\hline
\end{tabular}

The numbers represent $p$ values for the unit root tests. REER and TOT are expressed in natural logs. The null for Im et al. (2003) is that all panels contain unit roots. Maddala and Wu (1999) and Pesaran (2007) test the null hypothesis that series are integrated of order 1. Maddala and Wu (1999) assumes cross-section independence; Pesaran (2007) test assumes cross-section dependence in the form of a single unobserved common factor. The 11 countries included in the data set are Austria, Belgium, Finland, France, Germany, Ireland, Italy, Luxembourg, Netherlands, Portugal, and Spain. The observation period is 1999Q1-2017Q4

value added over total employment; the monetary variable considered is the longterm interest rate on government bonds. The vector of fiscal variables $F_{i t}^{m}$ includes government spending, total revenues and the VAT and SSCs tax wedges. $\delta_{i}$ is the 
country-specific intercept and, lastly, $\varepsilon_{i, t}$ is the error term. Time effects, $z_{t}$, includes quarterly fixed effects to capture seasonal patterns in the data and a dummy variable for the crisis, which takes value 1 from 2008Q1 to 2011Q4.

The parameters $\beta_{i}^{v}$ and $\beta_{i}^{m}$ show the long-run equilibrium relationship between each international relative price and the vector of its non-fiscal and fiscal determinants. The contemporaneous impact of an increase in each non-fiscal and fiscal control is given by the coefficient on the differenced variable, $b_{i}^{v}$ and $b_{i}^{m}$.

The term in round brackets in Eq. (1) represents the candidate cointegrating relationship we seek to identify in our panel time series approach. By relaxing the common factor restriction implicit in the nonlinear relationship between parameters in Eq. (1), the model can be parameterized as follows:

$$
\Delta P_{i, t}=\pi_{i}^{c} P_{i t-1}+\sum_{v} \pi_{i}^{v} X_{i t}^{v}+\sum_{m} \pi_{i}^{v} F_{i t}^{m}+\sum_{v} b_{i}^{v} \Delta X_{i t}^{v}+\sum_{m} b_{i}^{m} \Delta F_{i t}^{m}+z_{t}+\delta_{i}+\varepsilon_{i, t}
$$

Long-run parameters can be calculated from the coefficients on the terms in levels $\pi_{i}^{v}$, since $\beta_{i}^{v}=-\frac{\pi_{i}^{v}}{\pi_{i}^{c}}$ and $\beta_{i}^{m}=-\frac{\pi_{i}^{m}}{\pi_{i}^{c}}$. The coefficient $\beta_{i}^{c}=-\varphi_{i}$ measures the speed of convergence of the economy to its long-run equilibrium. Inference on this parameter will provide evidence of the presence of a long-run equilibrium relationship, if this parameter is null there is no cointegration, and the model reduces to a regression with variables in first differences (Eberhardt and Presbitero 2015). Otherwise, if $\varphi_{i} \neq 0$ variables in round brackets in Eq. (1) are cointegrated, and after a shock, the economy returns to the long-run equilibrium path.

Different specifications of the ECM could be tested according to the homogeneity assumptions imposed on the short and long-run coefficients. However, as pointed out by Xing (2012), the homogeneity restriction could be invalid for some coefficients leading sometimes to biased estimates. We thus test whether we can rely on the homogeneity hypothesis using the modified Wald test suggested by Xing (2012). ${ }^{3}$ The results show that we cannot accept this restriction for almost all the coefficients and for all the variables jointly in all the specifications estimated. For this reason, we run regressions without imposing short-run and long-run coefficients homogeneity by estimating the ECM in the mean group (MG) version.

A weakness of previous studies is that they largely disregard the possible presence of cross-sectional dependence in the panel. Our contribution in this sense is to estimate an econometric specification that explicitly addresses the presence of unobservable common factors controlling for the cross-sectional dependence. ${ }^{4}$ To

\footnotetext{
3 Results available upon request.

4 We investigate the possible presence of cross-sectional dependence in each single variable using the Pesaran (2004) CD test and find that most of the variables are affected by the presence of common factors. Results available upon request.
} 
this end, we follow the common correlated effects (CCE) approach suggested by Pesaran (2006) and employ cross-section averages of all variables in the model. This approach allows each country to have its own slope coefficients both on the observed explanatory variables and on the unobserved common factors. The estimation equation is thus:

$$
\begin{aligned}
& \Delta P_{i, t}=\pi_{i}^{c} P_{i t-1}+\sum_{v} \pi_{i}^{v} X_{i t}^{v}+\sum_{m} \pi_{i}^{m} F_{i t}^{m}+\sum_{v} b_{i}^{v} \Delta X_{i t}^{v}+\sum_{m} b_{i}^{m} \Delta F_{i t}^{m}+\sigma_{i}^{c} \bar{P}_{i t-1} \\
& +\sum_{v} \sigma_{i}^{v} \bar{X}_{i t}^{v}+\sum_{m} \sigma_{i}^{m} \bar{F}_{i t}^{m}+\lambda_{i} \Delta \bar{P}_{i t-1}+\sum_{v} \lambda_{i}^{v} \Delta \bar{X}_{i t}^{v}+\sum_{m} \lambda_{i}^{m} \Delta \bar{F}_{i t}^{m}+z_{t}+\delta_{i}+\varepsilon_{i, t} .
\end{aligned}
$$

The CCE approach has been shown to be robust to different types of cross-section dependence of errors, possible unit roots in explanatory variables, and slope heterogeneity (Pesaran and Tosetti 2011; Chudik et al. 2011). Recent work by Chudik and Pesaran (2015) highlights that in a dynamic panel, and/or in the presence of weakly exogenous variables as regressors, this approach is subject to bias. The authors suggest that the CCE approach continues to be valid if a sufficient number of lags of cross-section averages are included in Eq. (3). In the analysis, we adopt the standard CCE estimator in the mean group version (CMG) adjusted to a dynamic setup (Chudik and Pesaran 2015).

Finally, to assess the effects of unilateral and simultaneous fiscal devaluations we take into consideration changes in tax wedges in each domestic country (VAT and SSC) and its trading partners (VAT_TP and SSC_TP). The latter are computed by taking the geometric weighted average (considering trade weights) for the trading partners' tax wedge values.

To compute the impact of a unilateral V-FD we combine the estimated coefficients on VAT and SSC. Thus, the short-run impact of a fiscal devaluation is calculated as follows:

$$
\mathrm{FD}_{\mathrm{SR}}=b_{i}^{\mathrm{VAT}}-b_{i}^{\mathrm{SSC}} \text {, }
$$

whereas the long-run impact is given by:

$$
\mathrm{FD}_{\mathrm{LR}}=-\left(\beta_{i}^{\mathrm{VAT}}-\beta_{i}^{\mathrm{SSC}}\right) / \varphi_{i}
$$

Symmetrically, the effects on the domestic economy of a fiscal devaluation implemented by all trading partner countries is:

$$
\begin{aligned}
& \mathrm{FD}_{-}{ }_{\mathrm{TP}} \mathrm{SR}_{i}=b_{i}^{\mathrm{VAT} \_\mathrm{TP}}-b_{i}^{\mathrm{SSC} \_\mathrm{TP}}, \\
& \mathrm{FD}_{-} \mathrm{TP} \mathrm{LR}_{\mathrm{LR}}=-\left(\beta_{i}^{\mathrm{VAT} \_\mathrm{TP}}-\beta_{i}^{\mathrm{SSC} \_\mathrm{TP}}\right) / \varphi_{i} .
\end{aligned}
$$

The overall effect of a V-FD (from the domestic country's perspective) is computed by averaging the impacts of a 1 per cent fiscal devaluation in the domestic economy and an equal rate fiscal revaluation by its trading partners, as described by the following formulae for the short and the long run, respectively: 


$$
\begin{aligned}
\text { Overall } \mathrm{FD}_{\mathrm{SR}} & =\frac{\left[\left(b_{i}^{\mathrm{VAT}}-b_{i}^{\mathrm{SSC}}\right)-\left(b_{i}^{\mathrm{VAT} \_\mathrm{TP}}-b_{i}^{\mathrm{SSC} \mathrm{TP}^{\mathrm{TP}}}\right)\right]}{2}, \text { and } \\
\text { Overall } \mathrm{FD}_{\mathrm{LR}} & =\frac{\left[\left(-\left(\beta_{i}^{\mathrm{VAT}}-\beta_{i}^{\mathrm{SSC}}\right) / \varphi_{i}\right)+\left(-\left(\beta_{i}^{\mathrm{VAT} \mathrm{TP}_{-}}-\beta_{i}^{\mathrm{SSC} \_\mathrm{TP}}\right) / \varphi_{i}\right)\right]}{2} .
\end{aligned}
$$

When the tax structure is measured using tax to GDP ratios or tax ratios the coefficients correctly measure the impact of a revenue-neutral tax shift, given that we control for the level of tax burden over GDP. In fact, a one-point increase in the VAT ratios (either over GDP or over total revenue) would be exactly compensated by a one-point reduction in SSCs. When we focus on implicit tax rates (ITRs) instead, we are considering two variables measured using the respective tax bases. Moreover, since SSCs tax base is usually narrower than the VAT tax base (Koske 2013) a revenue-neutral tax shift would require a cut in the SSCs implicit tax rates higher than the VAT increase. To overcome these concerns and estimating the effects of a compensating change in VAT and SSCs implicit tax rates, we run the analysis using as tax measure implicit tax rates, holding tax bases constant: consumption (ITR/C) and labour (ITR/L), respectively. This in practice means that when we use ITR/C we are considering a one-point increase in the VAT implicit tax rate that can exactly offset a SSCs reduction, leaving revenue unchanged.

\section{Data}

We combine different data sources to obtain a cross-country unbalanced panel dataset and perform the analysis for 11 EA countries ${ }^{5}$ over the period ranging from 1999 to 2017 with quarterly frequency. We focus on the group of member states that have joined the EA since 1999 because the interest here is on the effect of a shock in the tax mix for countries that have shared a fixed nominal exchange rate. The analysis is performed on the CPI deflated REER and is then replicated for the TOT, both computed vis-à-vis the rest of the EA countries. ${ }^{6}$

To control for the possibility of simultaneous fiscal policies, the model considers the tax structure for each individual country and for its trading partners. Aggregation for trading partners' tax variables is done by a geometric average, using overall time-varying trade weights (taking into account third market effects) provided by Eurostat. $^{7}$

Tax variables are computed using either tax to GDP ratios, tax ratios or implicit tax rates. The numerator of the effective tax rates is given by the revenue of VAT and SSC by Eurostat. Implicit tax rates are obtained by taking the ratio with sum of private and government consumption from Eurostat National Accounts for VAT and

\footnotetext{
5 The countries considered are: Austria, Belgium, Finland, France, Germany, Ireland, Italy, Luxembourg, Netherlands, Portugal and Spain.

${ }^{6}$ For both the REER and the TOT an increase in the index is considered as an appreciation of the relative price.

7 The same weights are used to construct the REER and the TOT.
} 
a proxy for the labour income for SSC. Tax ratios are obtained by dividing revenues from each tax by total tax revenues. Since our focus is on a revenue-neutral tax shift, we control in the estimations for the overall tax burden over GDP (T).

Our empirical specification considers some variables suggested by the literature as relative price determinants, among which is productivity. A well-established result in the literature is the so-called Balassa (1964)-Samuelson (1964) mechanism, which states that relatively larger increases in productivity in the traded goods sector in a country should be associated with a REER appreciation of the currency of that country (Candelon et al. 2007; Galstyan and Lane 2009; Griffoli et al. 2015). As far as the TOT is concerned, a common view in trade and growth theory is that it should deteriorate after a rise in the supply of domestic goods since the increased domestic supply could be absorbed by international markets at falling prices. The empirical evidence about the dynamics of the TOT is mixed and it sometimes departs from theoretical predictions. Some studies document a positive relationship between productivity and TOT (Ghironi and Melitz 2005), others argue that the TOT depreciates after a productivity increase or that the effect is heterogeneous across countries (Corsetti et al. 2006; Corsetti et al. 2007). Alternative measures can be used to consider diverging productivity trends (Égert et al. 2006; Ricci et al. 2013). Here we focus on the labour productivity differential between tradables and nontradables (Y).

The relationship with the fiscal balance is also considered to be of interest, as it constitutes one of the key components of national savings. A fiscal tightening causes a permanent increase in the net foreign assets position of a country and, consequently, an appreciation of its exchange rate in the longer term (Bénétrix and Lane 2013; De Castro and Garrote 2015). Furthermore, intertemporal business cycle models predict that exogenous increase in government spending leads to significant terms of trade movements (Corsetti et al. 2007; Monacelli and Perotti 2008; Enders et al. 2011). We control for these potential effects by including in the regression government expenditure $(\mathrm{G})$, computed as the sum of government consumption and government investment, divided by GDP.

International relative prices may be affected by shocks in the domestic demand due to intra-EA capital inflows. Since capital flows may be largely affected by differences in return, we include in the list of the controls the long-term central government bond yields on the secondary market (I), which is a proxy for the interest rate. Capital inflows following an increase in interest rates should boost the economic activity and internal demand and thus should appreciate the real exchange rate and depreciate the terms of trade.

After investigating the effects on relative prices, we also provide evidence on the effects of a tax shift on net exports (computed as a percentage of GDP) for our sample countries. To this end, following the existing literature (De Mooij and Keen 2013; Holzner et al. 2018) we use as control variables the GDP growth rate (GDP) (in \%), the dependency ratio (DEP) (in \%), the unemployment rate (UR) (in \%), the general government balance (GGbal) (in \% of GDP) and revenues other than that from VAT and SSCs (REV) (in \% of GDP).

Details of data sources, variables definition and descriptive statistics of key variables are provided in Appendix. 
Table 2 CMG estimates on the REER

$\begin{array}{lllll}\text { Tax-GDP } & \text { TR } & \text { ITR } & \text { ITR/C } & \text { ITR/L } \\ (1) & (2) & (3) & (4) & (5)\end{array}$

\begin{tabular}{|c|c|c|c|c|c|}
\hline \multicolumn{6}{|l|}{ Long run } \\
\hline $\mathrm{Y}$ & $\begin{array}{l}0.0001 \\
(0.0001)\end{array}$ & $\begin{array}{l}0.00001 \\
(0.0001)\end{array}$ & $\begin{array}{l}-0.0001 \\
(0.0001)\end{array}$ & $\begin{array}{l}-0.00003 \\
(0.0001)\end{array}$ & $\begin{array}{l}-0.0001 * * \\
(0.0001)\end{array}$ \\
\hline $\mathrm{I}$ & $\begin{array}{l}-0.0073 \\
(0.0095)\end{array}$ & $\begin{array}{l}-0.0057 \\
(0.0066)\end{array}$ & $\begin{array}{l}-0.0044 \\
(0.0070)\end{array}$ & $\begin{array}{l}-0.0052 \\
(0.0085)\end{array}$ & $\begin{array}{l}-0.0027 \\
(0.0084)\end{array}$ \\
\hline G & $\begin{array}{l}0.0124 \\
(0.0116)\end{array}$ & $\begin{array}{l}0.0069 \\
(0.0063)\end{array}$ & $\begin{array}{l}0.0051 \\
(0.0040)\end{array}$ & $\begin{array}{l}0.0129 \\
(0.0149)\end{array}$ & $\begin{array}{l}0.0075 \\
(0.0051)\end{array}$ \\
\hline $\mathrm{T}$ & $\begin{array}{l}-0.0017 \\
(0.0034)\end{array}$ & $\begin{array}{l}0.0034 \\
(0.0026)\end{array}$ & $\begin{array}{l}-0.0007 \\
(0.0018)\end{array}$ & $\begin{array}{l}-0.0002 \\
(0.0037)\end{array}$ & $\begin{array}{l}-0.00003 \\
(0.0023)\end{array}$ \\
\hline VAT & $\begin{array}{l}0.0228 * * \\
(0.0104)\end{array}$ & $\begin{array}{l}0.0043 \\
(0.0026)\end{array}$ & $\begin{array}{l}0.0077 \\
(0.0079)\end{array}$ & $\begin{array}{l}0.0100 \\
(0.0084)\end{array}$ & $\begin{array}{l}0.0024 \\
(0.0052)\end{array}$ \\
\hline $\mathrm{SSC}$ & $\begin{array}{l}0.0481 \\
(0.0344)\end{array}$ & $\begin{array}{l}0.0103 \\
(0.0070)\end{array}$ & $\begin{array}{l}-0.0019 \\
(0.0139)\end{array}$ & $\begin{array}{l}0.0200 \\
(0.0215)\end{array}$ & $\begin{array}{l}-0.0055 \\
(0.0177)\end{array}$ \\
\hline $\mathrm{VAT}_{-} \mathrm{TP}$ & $\begin{array}{l}-0.0685 \\
(0.0676)\end{array}$ & $\begin{array}{l}-0.0003 \\
(0.0097)\end{array}$ & $\begin{array}{l}-0.0060 \\
(0.0424)\end{array}$ & $\begin{array}{l}-0.0061 \\
(0.0457)\end{array}$ & $\begin{array}{l}-0.0313 \\
(0.0380)\end{array}$ \\
\hline $\mathrm{SSC}_{-} \mathrm{TP}$ & $\begin{array}{l}0.1502 \\
(0.1405)\end{array}$ & $\begin{array}{l}0.0548 \\
(0.0385)\end{array}$ & $\begin{array}{l}-0.0248 \\
(0.0501)\end{array}$ & $\begin{array}{l}0.1538 \\
(0.1156)\end{array}$ & $\begin{array}{l}-0.0273 \\
(0.0706)\end{array}$ \\
\hline \multicolumn{6}{|l|}{ Short run } \\
\hline D.Y & $\begin{array}{l}0.000005 \\
(0.00001)\end{array}$ & $\begin{array}{l}0.000002 \\
(0.00001)\end{array}$ & $\begin{array}{l}0.00001 \\
(0.00001)\end{array}$ & $\begin{array}{l}0.00001 \\
(0.00001)\end{array}$ & $\begin{array}{l}0.000004 \\
(0.00001)\end{array}$ \\
\hline D.I & $\begin{array}{l}0.0053 * * * \\
(0.00046)\end{array}$ & $\begin{array}{l}0.0051 * * * \\
(0.0006)\end{array}$ & $\begin{array}{l}0.0057 * * * \\
(0.0005)\end{array}$ & $\begin{array}{l}0.0053 * * * \\
(0.0005)\end{array}$ & $\begin{array}{l}0.0054 * * * \\
(0.0005)\end{array}$ \\
\hline D.G & $\begin{array}{l}0.000003 \\
(0.00022)\end{array}$ & $\begin{array}{l}0.0002 \\
(0.0002)\end{array}$ & $\begin{array}{l}0.00003 \\
(0.0003)\end{array}$ & $\begin{array}{l}0.0003 \\
(0.0003)\end{array}$ & $\begin{array}{l}-0.000002 \\
(0.0003)\end{array}$ \\
\hline D.T & $\begin{array}{l}-0.0001 \\
(0.00013)\end{array}$ & $\begin{array}{l}-0.0003^{* *} \\
(0.0002)\end{array}$ & $\begin{array}{l}-0.0002 \\
(0.0001)\end{array}$ & $\begin{array}{l}-0.0002 * * * \\
(0.0001)\end{array}$ & $\begin{array}{l}-0.0001 \\
(0.0002)\end{array}$ \\
\hline D.VAT & $\begin{array}{l}-0.0012 \\
(0.00084)\end{array}$ & $\begin{array}{l}-0.0004 \\
(0.0003)\end{array}$ & $\begin{array}{l}0.0002 \\
(0.0004)\end{array}$ & $\begin{array}{l}-0.0003 \\
(0.0006)\end{array}$ & $\begin{array}{l}0.0002 \\
(0.0003)\end{array}$ \\
\hline D.SSC & $\begin{array}{l}-0.0018 \\
(0.0015)\end{array}$ & $\begin{array}{l}-0.0003 \\
(0.0005)\end{array}$ & $\begin{array}{l}-0.0021 * * * \\
(0.0008)\end{array}$ & $\begin{array}{l}-0.0012 * * \\
(0.0006)\end{array}$ & $\begin{array}{l}-0.0017 * * * \\
(0.0007)\end{array}$ \\
\hline D.VAT_TP & $\begin{array}{l}0.0028 \\
(0.00530)\end{array}$ & $\begin{array}{l}0.0011 \\
(0.0015)\end{array}$ & $\begin{array}{l}0.0026 \\
(0.0028)\end{array}$ & $\begin{array}{l}0.0034 \\
(0.0034)\end{array}$ & $\begin{array}{l}0.0025 \\
(0.0030)\end{array}$ \\
\hline D.SSC_TP & $\begin{array}{l}-0.0121 * \\
(0.0068)\end{array}$ & $\begin{array}{l}-0.0040 \\
(0.0026)\end{array}$ & $\begin{array}{l}-0.0066^{* * *} \\
(0.0029)\end{array}$ & $\begin{array}{l}-0.0074 * \\
(0.0041)\end{array}$ & $\begin{array}{l}-0.0065^{* * *} \\
(0.0025)\end{array}$ \\
\hline Convergence rate & $\begin{array}{l}-0.1753 * * * \\
(0.0354)\end{array}$ & $\begin{array}{l}-0.1817 * * * \\
(0.0360)\end{array}$ & $\begin{array}{l}-0.1319 * * * \\
(0.0422)\end{array}$ & $\begin{array}{l}-0.2024 * * * \\
(0.0421)\end{array}$ & $\begin{array}{l}-0.1351^{* * *} \\
(0.0413)\end{array}$ \\
\hline Obs. & 803 & 803 & 803 & 803 & 803 \\
\hline $\mathrm{CD}$ & -2.07 & -1.83 & -1.7 & -0.33 & -1.5 \\
\hline
\end{tabular}

Results for a sample of 11 EA countries covering the period 1999Q1-2017Q4 based on the CMG estimator adjusted to the dynamic setup with one additional lag of cross-sectional averages (Chudik and Pesaran, 2015). Each estimation contains quarterly dummies and a dummy for the crisis (assuming value 1 from 2008Q1 to 2011Q4). The dependent variable is the first difference of the log of the CPI deflated REER. CD reports the Pesaran (2015) test for cross-section dependence based on residuals. The following symbols indicate different significance levels: ***significant at $1 \%$; **significant at $5 \%$; *significant at $10 \%$. SE in parenthesis 
Table 3 Effects of fiscal devaluation on the REER

$\begin{array}{lllll}\text { Tax-GDP } & \text { TR } & \text { ITR } & \text { ITR_C } & \text { ITR_L } \\ (1) & (2) & (3) & (4) & (5)\end{array}$

Panel A: FD

$\begin{array}{llllll}\text { Short run } & 0.001 & -0.0001 & 0.002^{* * *} & 0.001 & 0.002^{* * *} \\ & (0.001) & (0.001) & (0.001) & (0.001) & (0.001) \\ \text { Long run } & -0.025 & -0.006 & 0.009 & -0.01 & 0.008 \\ & (0.030) & (0.005) & (0.014) & (0.021) & (0.016)\end{array}$

Panel B: $F D \_T P$

$\begin{array}{llllll}\text { Short run } & 0.015 * & 0.005 & 0.009 * * & 0.011^{* *} & 0.009 * * \\ & (0.008) & (0.003) & (0.004) & (0.005) & (0.004) \\ \text { Long run } & -0.219 & -0.055 & 0.019 & -0.159 & -0.004 \\ & (0.180) & (0.044) & (0.079) & (0.131) & (0.097)\end{array}$

Panel C: Overall FD

\begin{tabular}{llllll} 
Short run & $-0.007^{*}$ & -0.003 & $-0.003^{* *}$ & $-0.005^{* *}$ & $-0.004^{*}$ \\
& $(0.004)$ & $(0.002)$ & $(0.002)$ & $(0.002)$ & $(0.002)$ \\
Long run & 0.097 & 0.025 & -0.005 & 0.075 & 0.006 \\
& $(0.091)$ & $(0.023)$ & $(0.035)$ & $(0.056)$ & $(0.043)$ \\
\hline
\end{tabular}

The table reports the estimated effects of a fiscal devaluation calculated by taking the difference between VAT and SSCs tax wedges computed using the measure indicated in the first row, based on the estimations reported in Table 2 . The following symbols indicate different significance levels: ***significant at $1 \%$; **significant at $5 \%$; *significant at $10 \%$. SE in parenthesis

\section{Results}

This section presents our econometric results, first on relative prices and then on net exports. In particular, in Tables 2 and 4, we report results of the regression on the $\log$ of the REER and on the log of the TOT, respectively. The tables report the common correlated effects estimator in the mean group version adjusted to the dynamic setup with the inclusion of one additional lag of cross-section averages (CMG) as suggested by Chudik and Pesaran (2015). The quite low value of the Pesaran (2015) $\mathrm{CD}$ test, reported in the last row of the tables, suggests that our estimates properly account for the cross-sectional dependence.

We estimate five different specifications according to the measure used to compute tax wedges. In column 1 the tax structure is measured using tax to GDP ratios (Tax-GDP); in columns 2 and 3 we use respectively tax ratios (TR) and implicit tax rates (ITR); in the last two columns of the tables the tax structure is measured using implicit tax rates holding tax bases constant: consumption (ITR/C) and labour (ITR/L), respectively. The effects of the tax policy are detected through changes in VAT and SSCs tax wedges in each individual country (VAT and SSC) and in its trading partners (VAT_TP and SSC_TP). We report the estimated effects of a V-FD in Tables 3 and 5. In particular, panel A reports the estimated effects of a unilateral policy implemented by the domestic economy (FD), symmetrically, panel B shows the effects of the policy conducted by trading partners (FD_TP). Finally, in panel $\mathrm{C}$ we report the overall effect of a V-FD (Overall FD), computed assuming 
Table 4 CMG estimates on the TOT

$\begin{array}{lllll}\text { Tax-GDP } & \text { TR } & \text { ITR } & \text { ITR/C } & \text { ITR/L } \\ (1) & (2) & (3) & (4) & (5)\end{array}$

\begin{tabular}{|c|c|c|c|c|c|}
\hline \multicolumn{6}{|l|}{ Long run } \\
\hline $\mathrm{Y}$ & $\begin{array}{l}0.0002 * * \\
(0.0001)\end{array}$ & $\begin{array}{l}0.0002^{* *} \\
(0.0001)\end{array}$ & $\begin{array}{l}0.0002 * * * \\
(0.0001)\end{array}$ & $\begin{array}{l}0.0002 * * * \\
(0.0001)\end{array}$ & $\begin{array}{l}0.0002 * * * \\
(0.0001)\end{array}$ \\
\hline $\mathrm{I}$ & $\begin{array}{l}-0.0015 \\
(0.0047)\end{array}$ & $\begin{array}{l}-0.0016 \\
(0.0036)\end{array}$ & $\begin{array}{l}-0.0037 \\
(0.0066)\end{array}$ & $\begin{array}{l}-0.0025 \\
(0.0058)\end{array}$ & $\begin{array}{l}-0.0017 \\
(0.0057)\end{array}$ \\
\hline G & $\begin{array}{l}0.0014 \\
(0.0032)\end{array}$ & $\begin{array}{l}0.0034 \\
(0.0032)\end{array}$ & $\begin{array}{l}0.0054 \\
(0.0035)\end{array}$ & $\begin{array}{l}0.0047 * \\
(0.0025)\end{array}$ & $\begin{array}{l}0.0024 \\
(0.0029)\end{array}$ \\
\hline $\mathrm{T}$ & $\begin{array}{l}0.0028 \\
(0.0019)\end{array}$ & $\begin{array}{l}0.0000 \\
(0.0023)\end{array}$ & $\begin{array}{l}0.0021 \\
(0.0024)\end{array}$ & $\begin{array}{l}0.0012 \\
(0.0018)\end{array}$ & $\begin{array}{l}0.0024 \\
(0.0024)\end{array}$ \\
\hline VAT & $\begin{array}{l}-0.0074 \\
(0.0104)\end{array}$ & $\begin{array}{l}-0.0057 \\
(0.0041)\end{array}$ & $\begin{array}{l}-0.0073 \\
(0.0056)\end{array}$ & $\begin{array}{l}-0.0037 \\
(0.0064)\end{array}$ & $\begin{array}{l}-0.0019 \\
(0.0052)\end{array}$ \\
\hline SSC & $\begin{array}{l}-0.0101 \\
(0.0110)\end{array}$ & $\begin{array}{l}-0.0035 \\
(0.0031)\end{array}$ & $\begin{array}{l}0.0011 \\
(0.0084)\end{array}$ & $\begin{array}{l}0.0001 \\
(0.0080)\end{array}$ & $\begin{array}{l}0.0031 \\
(0.0081)\end{array}$ \\
\hline VAT_TP & $\begin{array}{l}-0.0020 \\
(0.0716)\end{array}$ & $\begin{array}{l}-0.0302 \\
(0.0261)\end{array}$ & $\begin{array}{l}-0.0315 \\
(0.0420)\end{array}$ & $\begin{array}{l}-0.0256 \\
(0.0413)\end{array}$ & $\begin{array}{l}-0.0286 \\
(0.0357)\end{array}$ \\
\hline $\mathrm{SSC}_{-} \mathrm{TP}$ & $\begin{array}{l}0.0689 \\
(0.0796)\end{array}$ & $\begin{array}{l}0.0132 \\
(0.0424)\end{array}$ & $\begin{array}{l}0.0754 \\
(0.0514)\end{array}$ & $\begin{array}{l}0.0627 \\
(0.0465)\end{array}$ & $\begin{array}{l}0.0668 \\
(0.0457)\end{array}$ \\
\hline \multicolumn{6}{|l|}{ Short run } \\
\hline D.Y & $\begin{array}{l}0.00001 \\
(0.00003)\end{array}$ & $\begin{array}{l}-0.00001 \\
(0.00004)\end{array}$ & $\begin{array}{l}-0.00001 \\
(0.00004)\end{array}$ & $\begin{array}{l}-0.00001 \\
(0.00004)\end{array}$ & $\begin{array}{l}-0.00002 \\
(0.00001)\end{array}$ \\
\hline D.I & $\begin{array}{l}-0.0005 \\
(0.0010)\end{array}$ & $\begin{array}{l}-0.0003 \\
(0.0012)\end{array}$ & $\begin{array}{l}-0.0005 \\
(0.0013)\end{array}$ & $\begin{array}{l}-0.0017 \\
(0.0012)\end{array}$ & $\begin{array}{l}-0.0001 \\
(0.0010)\end{array}$ \\
\hline D.G & $\begin{array}{l}0.0009 \\
(0.0017)\end{array}$ & $\begin{array}{l}-0.0004 \\
(0.0011)\end{array}$ & $\begin{array}{l}-0.0006 \\
(0.0018)\end{array}$ & $\begin{array}{l}-0.0002 \\
(0.0016)\end{array}$ & $\begin{array}{l}0.0002 \\
(0.0013)\end{array}$ \\
\hline D.T & $\begin{array}{l}-0.0009 \\
(0.0006)\end{array}$ & $\begin{array}{l}-0.0005 \\
(0.0007)\end{array}$ & $\begin{array}{l}-0.0006 \\
(0.0006)\end{array}$ & $\begin{array}{l}-0.0006 \\
(0.0004)\end{array}$ & $\begin{array}{l}-0.0007 \\
(0.0006)\end{array}$ \\
\hline D.VAT & $\begin{array}{l}0.0015 \\
(0.0022)\end{array}$ & $\begin{array}{l}0.0026^{* *} \\
(0.0010)\end{array}$ & $\begin{array}{l}0.0022 * * \\
(0.0011)\end{array}$ & $\begin{array}{l}0.0009 \\
(0.0011)\end{array}$ & $\begin{array}{l}0.0010 \\
(0.0010)\end{array}$ \\
\hline D.SSC & $\begin{array}{l}-0.0081 \\
(0.0064)\end{array}$ & $\begin{array}{l}-0.0007 \\
(0.0024)\end{array}$ & $\begin{array}{l}-0.0062 \\
(0.0040)\end{array}$ & $\begin{array}{l}-0.0007 \\
(0.0053)\end{array}$ & $\begin{array}{l}-0.0058 \\
(0.0038)\end{array}$ \\
\hline D.VAT_TP & $\begin{array}{l}0.0134 \\
(0.0152)\end{array}$ & $\begin{array}{l}0.0168 * * \\
(0.0078)\end{array}$ & $\begin{array}{l}0.0069 \\
(0.0100)\end{array}$ & $\begin{array}{l}0.0085 \\
(0.0074)\end{array}$ & $\begin{array}{l}0.0085 \\
(0.0075)\end{array}$ \\
\hline D.SSC_TP & $\begin{array}{l}-0.0395 \\
(0.0240)\end{array}$ & $\begin{array}{l}-0.0186 \\
(0.0134)\end{array}$ & $\begin{array}{l}-0.0301 \\
(0.0186)\end{array}$ & $\begin{array}{l}-0.0526 \\
(0.0340)\end{array}$ & $\begin{array}{l}-0.0173 \\
(0.0115)\end{array}$ \\
\hline Convergence rate & $\begin{array}{l}-0.6160 * * * \\
(0.0777)\end{array}$ & $\begin{array}{l}-0.6175^{* * * *} \\
(0.0838)\end{array}$ & $\begin{array}{l}-0.5911 * * * \\
(0.0817)\end{array}$ & $\begin{array}{l}-0.62712 * * * \\
(0.0796)\end{array}$ & $\begin{array}{l}-0.5777 * * * \\
(0.0888)\end{array}$ \\
\hline Obs. & 803 & 803 & 803 & 803 & 803 \\
\hline $\mathrm{CD}$ & -2.760 & -2.7 & -3.14 & -3.5 & -2.72 \\
\hline
\end{tabular}

Results for a sample of 11 EA countries covering the period 1999Q1-2017Q4, based on the CMG estimator adjusted to the dynamic setup with one additional lag of cross-sectional averages (Chudik and Pesaran, 2015). Each estimation contains quarterly dummies and a dummy for the crisis (assuming value 1 from 2008Q1 to 2011Q4). The dependent variable is the first difference of the log of the TOT. CD reports the Pesaran (2015) test for cross-section dependence based on residuals. The following symbols indicate different significance levels: ***significant at $1 \%$; **significant at 5\%; *significant at $10 \%$. SE in parenthesis 
Table 5 Effects of fiscal devaluation on the TOT

$\begin{array}{lllll}\text { Tax-GDP } & \text { TR } & \text { ITR } & \text { ITR/C } & \text { ITR/L } \\ (1) & (2) & (3) & (4) & (5)\end{array}$

Panel A: FD

$\begin{array}{llllll}\text { Short run } & 0.010 & 0.0033 & 0.0084 * & 0.0016 & 0.0067 \\ & (0.008) & (0.003) & (0.005) & (0.005) & (0.005) \\ \text { Long run } & 0.003 & -0.0022 & -0.0084 & -0.0038 & -0.0051 \\ & (0.017) & (0.006) & (0.011) & (0.011) & (0.011)\end{array}$

Panel B: FD_TP

$\begin{array}{llllll}\text { Short run } & 0.053 & 0.0355^{* *} & 0.0370^{* *} & 0.0612^{*} & 0.0258^{*} \\ & (0.033) & (0.018) & (0.019) & (0.036) & (0.014) \\ \text { Long run } & -0.071 & -0.0434 & -0.1068 & -0.0883 & -0.0954 \\ & (0.131) & (0.058) & (0.077) & (0.080) & (0.074)\end{array}$

Panel C: overall FD

\begin{tabular}{llllll} 
Short run & -0.022 & $-0.0161^{*}$ & $-0.0143^{*}$ & $-0.0298^{*}$ & $-0.0096^{*}$ \\
& $(0.014)$ & $(0.009)$ & $(0.008)$ & $(0.016)$ & $(0.006)$ \\
Long run & 0.037 & 0.0206 & 0.0492 & 0.0423 & 0.0451 \\
& $(0.060)$ & $(0.028)$ & $(0.035)$ & $(0.036)$ & $(0.034)$ \\
\hline
\end{tabular}

The table reports the estimated effects of a fiscal devaluation calculated by taking the difference between VAT and SSCs tax wedges computed using the measure indicated in the first row, based on the estimations reported in Table 4 . The following symbols indicate different significance levels: $* * *$ significant at $1 \%$; **significant at $5 \%$; *significant at $10 \%$. SE in parenthesis

the possibility of a fiscal devaluation in the domestic country combined with a fiscal revaluation by trading partners.

In Tables 2 and 4, note that the convergence rate is negative and highly statistically significant, thus implying the presence of a cointegrating relationship. This means that we can rely on the long-run coefficients estimates, though in general these are not always statistically significant. This is particularly true for the estimated effects on fiscal devaluations reported in Tables 3 and 5. These are in general higher in magnitude with respect to the short-run effects, sometimes having the opposite sign, but are not statistically significant in all the specifications reported.

The estimated impacts of control variables on relative prices is consistent with the findings of previous literature, even if they are not always statistically significant. The REER is positively affected by an increase in the real interest rate in the short run, whereas a productivity shock affects the TOT in the long run.

Focusing on the effects on REER of a change in the domestic tax mix, we find that a unilateral VAT does not significantly impact either in the short or in the long run, whereas a SSCs increase leads to a significant short-run depreciation of the REER (Table 2, columns 3 through 5). When the estimated coefficients on VAT and SSCs are combined to capture the effect of a unilateral tax shift from SSC to VAT, the REER appreciates in the short run (panel A of Table 3). The effect, however, is significant only when the tax structure is measured using implicit tax rates (column 3) and implicit tax rates computed holding constant the labour tax base (column 5). The country's domestic REER appreciates also when the fiscal devaluation is 
implemented by trading partners (Table 3, panel B). These results are in contrast with Engler et al. (2017) who argue, by simulating a general equilibrium model, that the domestic REER should depreciate after a unilateral V-FD. There is weak evidence of a REER depreciation when simultaneous tax changes in domestic and foreign economies are taken into consideration. In fact, when we compute the average effect as a combination of a fiscal devaluation by the national economy and a fiscal revaluation (of the same amount) by trading partners (Table 3, panel C) we find an (albeit weakly significant) depreciation of the CPI deflated REER. The effect is rather small in magnitude, reaching 0.7 per cent when we use tax to GDP ratios (column 1).

Turning to the TOT, the effects seem to reverse when we look at single tax changes. A shock in the VAT rate significantly appreciates the TOT in the short run (Table 4, columns 2 and 3), whereas SSCs lead to a depreciation, albeit not statistically significant. However, when tax coefficients are combined (Table 5), the overall conclusions for the REER hold also for the TOT, even if in the latter case the effects are not in general statistically significant. A unilateral fiscal devaluation by national economies leads to a TOT appreciation, significant at 10 per cent only when we use implicit tax rates (panel A, column 3). We find that the TOT appreciates also in the case of a unilateral devaluation by trading partner countries (panel B). As in the case of the REER, so also for the TOT, we find the expected effects of a fiscal devaluation only when we consider simultaneous tax policies. In fact, panel $\mathrm{C}$ of Table 5 reports a weak depreciation of the TOT (from the domestic country perspective), significant only at 10 per cent level. The magnitude of the effect is higher than that on the REER, ranging from 0.96 up to 2.98 per cent.

Summarizing, our analysis provides only a weak support to the theoretical prediction that a fiscal devaluation would produce the same movements in the TOT and the REER brought about by a nominal devaluation: the relative prices both depreciate in the short run when a country shifts the tax wedge from SSCs to VAT while its trading partners do the opposite. However, the effects on relative prices are small in magnitude and not highly statistically significant.

We now turn to the question of whether a V-FD may have a significant impact on trade despite such weak effects on prices. The second part of our analysis focuses directly on this issue by analysing the effects of fiscal devaluations on net exports.

In order to allow the comparison between our estimates and those presented in previous research, we first assume both long-run and short-run homogeneity and ignore cross-sectional dependence using a dynamic fixed effect (DFE) specification of the ECM. Results are reported in Tables 6 and 7.

In contrast with existing studies (De Mooij and Keen 2013; Holzner et al. 2018), we find that net exports are significantly affected by control variables in the long run. In particular, net exports increase after a positive shock in both the unemployment rate (UR) and the general government balance over GDP (GGbal). The positive coefficient on the government budget balance is consistent with the positive relationship between government balances and current accounts over the medium 
Table 6 DFE estimates on net exports

$\begin{array}{lllll}\text { Tax-GDP } & \text { TR } & \text { ITR } & \text { ITR/C } & \text { ITR/L } \\ (1) & (2) & (3) & (4) & (5)\end{array}$

\begin{tabular}{|c|c|c|c|c|c|}
\hline \multicolumn{6}{|l|}{ Long run } \\
\hline GDP & $\begin{array}{l}0.143 \\
(0.264)\end{array}$ & $\begin{array}{l}0.206 \\
(0.272)\end{array}$ & $\begin{array}{l}0.219 \\
(0.275)\end{array}$ & $\begin{array}{l}0.238 \\
(0.277)\end{array}$ & $\begin{array}{l}0.241 \\
(0.258)\end{array}$ \\
\hline DEP & $\begin{array}{l}0.240 \\
(0.265)\end{array}$ & $\begin{array}{l}0.237 \\
(0.270)\end{array}$ & $\begin{array}{l}0.064 \\
(0.249)\end{array}$ & $\begin{array}{l}0.068 \\
(0.210)\end{array}$ & $\begin{array}{l}0.141 \\
(0.223)\end{array}$ \\
\hline UR & $\begin{array}{l}0.008 * * * \\
(0.002)\end{array}$ & $\begin{array}{l}0.009 * * * \\
(0.002)\end{array}$ & $\begin{array}{l}0.008 * * * \\
(0.001)\end{array}$ & $\begin{array}{l}0.008 * * * \\
(0.002)\end{array}$ & $\begin{array}{l}0.008 * * * \\
(0.001)\end{array}$ \\
\hline GGbal & $\begin{array}{l}0.451 * * \\
(0.188)\end{array}$ & $\begin{array}{l}0.482 * * \\
(0.194)\end{array}$ & $\begin{array}{l}0.359 * * * \\
(0.131)\end{array}$ & $\begin{array}{l}0.428 * * * \\
(0.138)\end{array}$ & $\begin{array}{l}0.395 * * * \\
(0.135)\end{array}$ \\
\hline REV & $\begin{array}{l}-0.660 * * * \\
(0.163)\end{array}$ & $\begin{array}{l}-0.684 * * \\
(0.330)\end{array}$ & $\begin{array}{l}-0.628 * * * \\
(0.172)\end{array}$ & $\begin{array}{l}-0.692^{* * * *} \\
(0.146)\end{array}$ & $\begin{array}{l}-0.644 * * * \\
(0.155)\end{array}$ \\
\hline VAT & $\begin{array}{l}-1.363^{*} \\
(0.755)\end{array}$ & $\begin{array}{l}-0.469 \\
(0.459)\end{array}$ & $\begin{array}{l}0.015 \\
(0.365)\end{array}$ & $\begin{array}{l}-0.208 \\
(0.273)\end{array}$ & $\begin{array}{l}-0.290 \\
(0.326)\end{array}$ \\
\hline SSC & $\begin{array}{l}0.234 \\
(1.491)\end{array}$ & $\begin{array}{l}0.469 \\
(0.792)\end{array}$ & $\begin{array}{l}1.728 * \\
(0.941)\end{array}$ & $\begin{array}{l}1.025 * \\
(0.572)\end{array}$ & $\begin{array}{l}1.795^{*} \\
(0.960)\end{array}$ \\
\hline $\mathrm{VAT}_{\text {TP }}$ & $\begin{array}{l}0.327 \\
(1.907)\end{array}$ & $\begin{array}{l}-0.333 \\
(0.843)\end{array}$ & $\begin{array}{l}0.076 \\
(0.711)\end{array}$ & $\begin{array}{l}-0.596 \\
(0.447)\end{array}$ & $\begin{array}{l}-0.611 \\
(0.609)\end{array}$ \\
\hline SSC_TP & $\begin{array}{l}4.039 * * * \\
(1.564)\end{array}$ & $\begin{array}{l}0.907 \\
(1.034)\end{array}$ & $\begin{array}{l}2.427 \\
(2.271)\end{array}$ & $\begin{array}{l}2.289 * * \\
(1.137)\end{array}$ & $\begin{array}{l}2.275 \\
(2.435)\end{array}$ \\
\hline \multicolumn{6}{|l|}{ Short run } \\
\hline D.GDP & $\begin{array}{l}-0.144 \\
(0.101)\end{array}$ & $\begin{array}{l}-0.142 \\
(0.097)\end{array}$ & $\begin{array}{l}-0.124 \\
(0.111)\end{array}$ & $\begin{array}{l}-0.143 \\
(0.111)\end{array}$ & $\begin{array}{l}-0.154 \\
(0.100)\end{array}$ \\
\hline D.DEP & $\begin{array}{l}-0.107 \\
(0.203)\end{array}$ & $\begin{array}{l}-0.051 \\
(0.193)\end{array}$ & $\begin{array}{l}-0.131 \\
(0.183)\end{array}$ & $\begin{array}{l}-0.102 \\
(0.183)\end{array}$ & $\begin{array}{l}-0.185 \\
(0.213)\end{array}$ \\
\hline D.UR & $\begin{array}{l}-0.001 \\
(0.002)\end{array}$ & $\begin{array}{l}-0.001 \\
(0.002)\end{array}$ & $\begin{array}{l}0.0001 \\
(0.002)\end{array}$ & $\begin{array}{l}-0.001 \\
(0.002)\end{array}$ & $\begin{array}{l}-0.001 \\
(0.002)\end{array}$ \\
\hline D.GGbal & $\begin{array}{l}-0.079 * \\
(0.042)\end{array}$ & $\begin{array}{l}-0.096^{* *} \\
(0.040)\end{array}$ & $\begin{array}{l}-0.074 \\
(0.046)\end{array}$ & $\begin{array}{l}-0.101 * * \\
(0.051)\end{array}$ & $\begin{array}{l}-0.079 * \\
(0.044)\end{array}$ \\
\hline D.REV & $\begin{array}{l}0.178 * * \\
(0.073)\end{array}$ & $\begin{array}{l}0.166 \\
(0.144)\end{array}$ & $\begin{array}{l}0.196 * * \\
(0.080)\end{array}$ & $\begin{array}{l}0.232 * * * \\
(0.076)\end{array}$ & $\begin{array}{l}0.205 * * * \\
(0.074)\end{array}$ \\
\hline D.VAT & $\begin{array}{l}0.509 \\
(0.350)\end{array}$ & $\begin{array}{l}0.219 \\
(0.176)\end{array}$ & $\begin{array}{l}0.199 \\
(0.127)\end{array}$ & $\begin{array}{l}0.261 * * \\
(0.115)\end{array}$ & $\begin{array}{l}0.246^{*} \\
(0.134)\end{array}$ \\
\hline D.SSC & $\begin{array}{l}-0.313 \\
(0.468)\end{array}$ & $\begin{array}{l}-0.343 \\
(0.234)\end{array}$ & $\begin{array}{l}-0.668 * * * \\
(0.242)\end{array}$ & $\begin{array}{l}-0.344 \\
(0.213)\end{array}$ & $\begin{array}{l}-0.708 * * * \\
(0.261)\end{array}$ \\
\hline D.VAT_TP & $\begin{array}{l}-0.987 \\
(0.967)\end{array}$ & $\begin{array}{l}-0.331 \\
(0.422)\end{array}$ & $\begin{array}{l}-0.264 \\
(0.475)\end{array}$ & $\begin{array}{l}-0.070 \\
(0.464)\end{array}$ & $\begin{array}{l}-0.355 \\
(0.408)\end{array}$ \\
\hline D.SSC_TP & $\begin{array}{l}-0.777 \\
(0.816)\end{array}$ & $\begin{array}{l}-0.197 \\
(0.374)\end{array}$ & $\begin{array}{l}-0.754 \\
(0.786)\end{array}$ & $\begin{array}{l}-0.289 \\
(0.574)\end{array}$ & $\begin{array}{l}-0.704 \\
(0.782)\end{array}$ \\
\hline Convergence rate & $\begin{array}{l}-0.500 * * * \\
(0.093)\end{array}$ & $\begin{array}{l}-0.490 * * * \\
(0.086)\end{array}$ & $\begin{array}{l}-0.508 * * * \\
(0.076)\end{array}$ & $\begin{array}{l}-0.519 * * * \\
(0.088)\end{array}$ & $\begin{array}{l}-0.509 * * * \\
(0.071)\end{array}$ \\
\hline Obs. & 753 & 753 & 753 & 753 & 753 \\
\hline $\mathrm{CD}$ & 10.11 & 20.15 & 23.90 & 13.82 & 20.15 \\
\hline
\end{tabular}

Results for a sample of 11 EA countries covering the period 1999Q1-2017Q4, based on the DFE estimator. Each estimation contains quarterly dummies and a dummy for the crisis (assuming value 1 from 2008Q1 to 2011Q4). The dependent variable is the first difference of net exports. CD reports the Pesaran (2015) test for cross-section dependence based on residuals. The following symbols indicate different significance levels: ***significant at $1 \%$; **significant at $5 \%$; *significant at $10 \%$. SE in parenthesis 
Table 7 Effects of fiscal devaluation on net exports (DFE estimates)

$\begin{array}{lllll}\text { Tax-GDP } & \text { TR } & \text { ITR } & \text { ITR/C } & \text { ITR/L } \\ (1) & (2) & (3) & (4) & (5)\end{array}$

\begin{tabular}{|c|c|c|c|c|c|}
\hline \multicolumn{6}{|c|}{ Panel A: FD } \\
\hline Short run & $\begin{array}{l}0.821^{*} \\
(0.460)\end{array}$ & $\begin{array}{l}0.562 * * * \\
(0.172)\end{array}$ & $\begin{array}{l}0.866^{* * * *} \\
(0.289)\end{array}$ & $\begin{array}{l}0.606^{* * * *} \\
(0.216)\end{array}$ & $\begin{array}{l}0.954 * * * \\
(0.298)\end{array}$ \\
\hline Long run & $\begin{array}{l}-1.597 \\
(1.508)\end{array}$ & $\begin{array}{l}-0.938 \\
(0.637)\end{array}$ & $\begin{array}{l}-1.713 \\
(1.143)\end{array}$ & $\begin{array}{l}-1.233^{*} \\
(0.731)\end{array}$ & $\begin{array}{l}-2.085^{*} \\
(1.144)\end{array}$ \\
\hline \multicolumn{6}{|c|}{ Panel B: FD_TP } \\
\hline Short run & $\begin{array}{l}-0.2102 \\
(0.978)\end{array}$ & $\begin{array}{l}-0.134 \\
(0.547)\end{array}$ & $\begin{array}{l}0.490 \\
(0.870)\end{array}$ & $\begin{array}{l}0.219 \\
(0.611)\end{array}$ & $\begin{array}{l}0.349 \\
(0.896)\end{array}$ \\
\hline Long run & $\begin{array}{l}-3.713^{*} \\
(2.214)\end{array}$ & $\begin{array}{l}1.239 \\
(1.021)\end{array}$ & $\begin{array}{l}2.351 \\
(2.200)\end{array}$ & $\begin{array}{l}-2.886^{* * *} \\
(1.157)\end{array}$ & $\begin{array}{l}-2.886 \\
(2.457)\end{array}$ \\
\hline \multicolumn{6}{|c|}{ Panel C: overall FD } \\
\hline Short run & $\begin{array}{l}0.516 \\
(0.485)\end{array}$ & $\begin{array}{l}0.348 \\
(0.297)\end{array}$ & $\begin{array}{l}0.188 \\
(0.442)\end{array}$ & $\begin{array}{l}0.193 \\
(0.258)\end{array}$ & $\begin{array}{l}0.302 \\
(0.411)\end{array}$ \\
\hline Long run & $\begin{array}{l}1.058 \\
(1.206)\end{array}$ & $\begin{array}{l}-1.089 * \\
(0.642)\end{array}$ & $\begin{array}{l}-2.032 \\
(1.443)\end{array}$ & $\begin{array}{l}0.826^{*} \\
(0.439)\end{array}$ & $\begin{array}{l}0.400 \\
(0.984)\end{array}$ \\
\hline
\end{tabular}

The table reports the estimated effect of a fiscal devaluation calculated by taking the difference between VAT and SSCs tax wedges computed using the measure indicated in the first row, based on the estimations reported in Table 6 . The following symbols indicate different significance levels: ***significant at $1 \%$; **significant at $5 \%$; *significant at $10 \%$. SE in parenthesis

term predicted by Obstfeld and Rogoff (1998) and documented by Chinn and Prasad (2003).

As to the tax variables, our results seem to confirm the findings of past analyses. A positive shock in the VAT tax wedge increases net exports, whereas an increase in SSCs has a negative impact on them. Taken together, the above effects lead to a significant short-run increase of net exports after a unilateral V-FD (Table 7, panel A). In particular, the trade balance improves by about 1 per cent when tax variables are computed using implicit tax rates over labour base (column 5). In the long run, as one would expect, the effects tend to reverse and are not statistically significant in almost all the specifications. When we focus on simultaneous tax changes (Table 7, panel C), even if the overall short-run effect of a V-FD has the expected sign in all the specifications, it is not statistically significant.

However, both the assumptions of homogeneity and cross-sectional independence are rejected by the data. The Wald test rejects the null hypothesis of equal long-run coefficients across countries. ${ }^{8}$ Moreover, the CD test in the last row of Table 6 shows that the residuals are affected by a strong cross-sectional correlation.

In Tables 8 and 9, we report results on net exports under our preferred model specification (CMG) which accounts for both coefficient heterogeneity and crosssectional dependence. First of all, it is worth noting that the CD statistic drops when we shift from the DFE to the CMG estimations (Table 8), entailing a significant reduction of cross-sectional dependence.

\footnotetext{
${ }^{8}$ Results available upon request.
} 
Table 8 CMG estimates on net exports

$\begin{array}{lllll}\text { Tax-GDP } & \text { TR } & \text { ITR } & \text { ITR/C } & \text { ITR/L } \\ (1) & (2) & (3) & (4) & (5)\end{array}$

\begin{tabular}{|c|c|c|c|c|c|}
\hline \multicolumn{6}{|l|}{ Long run } \\
\hline GDP & $\begin{array}{l}-0.001 \\
(0.110)\end{array}$ & $\begin{array}{l}0.017 \\
(0.100)\end{array}$ & $\begin{array}{l}0.035 \\
(0.115)\end{array}$ & $\begin{array}{l}0.018 \\
(0.134)\end{array}$ & $\begin{array}{l}-0.015 \\
(0.127)\end{array}$ \\
\hline DEP & $\begin{array}{l}-0.280 \\
(0.505)\end{array}$ & $\begin{array}{l}0.290 \\
(0.485)\end{array}$ & $\begin{array}{l}0.8530^{*} \\
(0.482)\end{array}$ & $\begin{array}{l}0.285 \\
(0.350)\end{array}$ & $\begin{array}{l}0.414 \\
(0.397)\end{array}$ \\
\hline UR & $\begin{array}{l}0.005 * * * \\
(0.001)\end{array}$ & $\begin{array}{l}0.007 * * * \\
(0.001)\end{array}$ & $\begin{array}{l}0.006^{* * * *} \\
(0.001)\end{array}$ & $\begin{array}{l}0.007 * * * \\
(0.002)\end{array}$ & $\begin{array}{l}0.006 * * * \\
(0.001)\end{array}$ \\
\hline GGbal & $\begin{array}{l}0.093 \\
(0.113)\end{array}$ & $\begin{array}{l}0.108 \\
(0.091)\end{array}$ & $\begin{array}{l}0.1735 * \\
(0.097)\end{array}$ & $\begin{array}{l}0.160 \\
(0.110)\end{array}$ & $\begin{array}{l}0.186^{*} \\
(0.112)\end{array}$ \\
\hline REV & $\begin{array}{l}0.090 \\
(0.222)\end{array}$ & $\begin{array}{l}-0.183 \\
(0.220)\end{array}$ & $\begin{array}{l}0.018 \\
(0.151)\end{array}$ & $\begin{array}{l}-0.058 \\
(0.170)\end{array}$ & $\begin{array}{l}0.003 \\
(0.207)\end{array}$ \\
\hline VAT & $\begin{array}{l}-1.350 \\
(1.010)\end{array}$ & $\begin{array}{l}-0.678 * * * \\
(0.244)\end{array}$ & $\begin{array}{l}-0.462 \\
(0.423)\end{array}$ & $\begin{array}{l}-0.111 \\
(0.426)\end{array}$ & $\begin{array}{l}-0.726 \\
(0.543)\end{array}$ \\
\hline $\mathrm{SSC}$ & $\begin{array}{l}-2.259 \\
(1.421)\end{array}$ & $\begin{array}{l}-0.236 \\
(0.567)\end{array}$ & $\begin{array}{l}-0.925 \\
(0.989)\end{array}$ & $\begin{array}{l}0.101 \\
(0.821)\end{array}$ & $\begin{array}{l}-1.182 \\
(0.840)\end{array}$ \\
\hline $\mathrm{VAT}_{-T P}$ & $\begin{array}{l}-7.419 \\
(6.816)\end{array}$ & $\begin{array}{l}-1.728 \\
(1.754)\end{array}$ & $\begin{array}{l}-1.972 \\
(3.069)\end{array}$ & $\begin{array}{l}-1.431 \\
(2.798)\end{array}$ & $\begin{array}{l}-1.481 \\
(2.838)\end{array}$ \\
\hline SSC_TP & $\begin{array}{l}-9.9047 * \\
(5.896)\end{array}$ & $\begin{array}{l}1.011 \\
(2.406)\end{array}$ & $\begin{array}{l}-0.994 \\
(3.022)\end{array}$ & $\begin{array}{l}0.598 \\
(3.618)\end{array}$ & $\begin{array}{l}-1.946 \\
(3.340)\end{array}$ \\
\hline \multicolumn{6}{|l|}{ Short run } \\
\hline D.GDP & $\begin{array}{l}-0.028 \\
(0.094)\end{array}$ & $\begin{array}{l}-0.022 \\
(0.090)\end{array}$ & $\begin{array}{l}-0.055 \\
(0.094)\end{array}$ & $\begin{array}{l}-0.063 \\
(0.090)\end{array}$ & $\begin{array}{l}-0.008 \\
(0.106)\end{array}$ \\
\hline D.DEP & $\begin{array}{l}2.359 \\
(1.539)\end{array}$ & $\begin{array}{l}2.290 \\
(1.479)\end{array}$ & $\begin{array}{l}1.610 \\
(1.276)\end{array}$ & $\begin{array}{l}2.685 \\
(1.657)\end{array}$ & $\begin{array}{l}1.934 \\
(1.362)\end{array}$ \\
\hline D.UR & $\begin{array}{l}0.000 \\
(0.001)\end{array}$ & $\begin{array}{l}0.005 \\
(0.003)\end{array}$ & $\begin{array}{l}0.000 \\
(0.002)\end{array}$ & $\begin{array}{l}0.001 \\
(0.003)\end{array}$ & $\begin{array}{l}0.001 \\
(0.002)\end{array}$ \\
\hline D.GGbal & $\begin{array}{l}-0.068 \\
(0.071)\end{array}$ & $\begin{array}{l}-0.095 \\
(0.070)\end{array}$ & $\begin{array}{l}-0.091 * \\
(0.049)\end{array}$ & $\begin{array}{l}-0.092 * * \\
(0.047)\end{array}$ & $\begin{array}{l}-0.109 * \\
(0.058)\end{array}$ \\
\hline D.REV & $\begin{array}{l}0.074 \\
(0.169)\end{array}$ & $\begin{array}{l}0.181 * \\
(0.105)\end{array}$ & $\begin{array}{l}0.030 \\
(0.119)\end{array}$ & $\begin{array}{l}0.111 \\
(0.136)\end{array}$ & $\begin{array}{l}0.033 \\
(0.137)\end{array}$ \\
\hline D.VAT & $\begin{array}{l}0.772 * * * \\
(0.222)\end{array}$ & $\begin{array}{l}0.379 * * * \\
(0.110)\end{array}$ & $\begin{array}{l}0.269 * * * \\
(0.066)\end{array}$ & $\begin{array}{l}0.227 * * * \\
(0.065)\end{array}$ & $\begin{array}{l}0.354 * * * \\
(0.107)\end{array}$ \\
\hline D.SSC & $\begin{array}{l}0.530 \\
(0.835)\end{array}$ & $\begin{array}{l}0.311 \\
(0.532)\end{array}$ & $\begin{array}{l}0.161 \\
(0.367)\end{array}$ & $\begin{array}{l}-0.238 \\
(0.188)\end{array}$ & $\begin{array}{l}0.243 \\
(0.495)\end{array}$ \\
\hline D.VAT_TP & $\begin{array}{l}-0.848 \\
(0.857)\end{array}$ & $\begin{array}{l}-0.166 \\
(0.538)\end{array}$ & $\begin{array}{l}-0.505 \\
(0.694)\end{array}$ & $\begin{array}{l}-0.526 \\
(0.566)\end{array}$ & $\begin{array}{l}-0.319 \\
(0.535)\end{array}$ \\
\hline D.SSC_TP & $\begin{array}{l}-1.293 \\
(1.177)\end{array}$ & $\begin{array}{l}0.028 \\
(0.299)\end{array}$ & $\begin{array}{l}-0.117 \\
(0.398)\end{array}$ & $\begin{array}{l}-0.373 \\
(0.407)\end{array}$ & $\begin{array}{l}-0.537 \\
(0.768)\end{array}$ \\
\hline Convergence rate & $\begin{array}{l}-0.861^{* * * *} \\
(0.071)\end{array}$ & $\begin{array}{l}-0.839 * * * \\
(0.076)\end{array}$ & $\begin{array}{l}-0.796^{* * * *} \\
(0.074)\end{array}$ & $\begin{array}{l}-0.793 * * * \\
(0.074)\end{array}$ & $\begin{array}{l}-0.823 * * * \\
(0.073)\end{array}$ \\
\hline Obs. & 753 & 753 & 753 & 753 & 753 \\
\hline $\mathrm{CD}$ & -0.140 & -0.430 & -0.540 & -0.030 & -0.170 \\
\hline
\end{tabular}

Results for a sample of 11 EA countries covering the period 1999Q1-2017Q4, based on the CMG estimator. Each estimation contains quarterly dummies and a dummy for the crisis (assuming value 1 from 2008Q1 to 2011Q4). The dependent variable is the first difference of net exports. CD reports the Pesaran (2015) test for cross-section dependence based on residuals. The following symbols indicate different significance levels: ***significant at $1 \%$; **significant at $5 \%$; *significant at $10 \%$. SE in parenthesis 
Table 9 Effects of fiscal devaluation on net exports (CMG estimates)

\begin{tabular}{llllll}
\hline \multicolumn{7}{c}{$\begin{array}{l}\text { Tax-GDP } \\
(1)\end{array}$} & $\begin{array}{l}\text { TR } \\
(2)\end{array}$ & $\begin{array}{l}\text { ITR } \\
(3)\end{array}$ & $\begin{array}{l}\text { ITR/C } \\
(4)\end{array}$ & $\begin{array}{l}\text { ITR/L } \\
(5)\end{array}$ \\
\hline Panel A: FD & & & & & \\
Short run & 0.242 & 0.069 & 0.108 & $0.466^{* *}$ & 0.110 \\
& $(0.731)$ & $(0.452)$ & $(0.405)$ & $(0.185)$ & $(0.478)$ \\
Long run & 0.908 & -0.442 & 0.463 & -0.211 & 0.456 \\
& $(1.824)$ & $(0.725)$ & $(0.783)$ & $(0.797)$ & $(0.892)$ \\
Panel B: FD_TP & & & & \\
Short run & 0.445 & -0.194 & -0.388 & -0.153 & 0.217 \\
& $(1.199)$ & $(0.549)$ & $(0.705)$ & $(0.505)$ & $(0.767)$ \\
Long run & 2.485 & 2.739 & 0.978 & -2.029 & 0.464 \\
& $(4.773)$ & $(3.940)$ & $(4.841$ & $(5.935)$ & $(4.936)$ \\
Panel C: average FD & & & & \\
Short run & -0.101 & 0.131 & 0.248 & 0.309 & -0.053 \\
& $(0.549)$ & $(0.286)$ & $(0.312)$ & $(0.285)$ & $(0.439)$ \\
\multicolumn{1}{l}{ Long run } & -0.789 & -1.590 & -0.257 & 0.909 & -0.004 \\
& $(2.208)$ & $(2.172)$ & $(2.676)$ & $(2.659)$ & $(2.182)$ \\
\hline
\end{tabular}

The table reports the estimated effect of a fiscal devaluation calculated by taking the difference between VAT and SSCs tax wedges computed using the measure indicated in the first row, based on the estimations reported in Table 8. The following symbols indicate different significance levels: $* * *$ significant at $1 \%$; $* *$ significant at $5 \%$; *significant at $10 \%$. SE in parenthesis

The estimated effects of fiscal devaluations are now smaller in magnitude and weaker in terms of significance. A unilateral V-FD still has a positive impact on the trade balance in the short run, but it turns out to be significant only in one case, when the tax structure is measured using implicit tax rates over consumption base (Table 9 , panel A, column 4). In this case, net export increases by 0.46 per cent, very close to the estimated coefficient in Holzner et al. (2018). When we turn to simultaneous tax policies, as in the DFE estimates, even if we document an improvement in the trade balance, the coefficient is not statistically significant in any of the specifications tested.

Summarizing, only in the most favourable scenario, in which the domestic country fiscally devalues and its trading partners implement a fiscal revaluation, does the analysis on international relative prices provide (weak) evidence in support of the theoretical prediction on V-FD, whereas we find no significant effect on quantities.

We further explore the heterogeneity of short- and long-run responses across countries by repeating the analysis for each cross-section unit separately. ${ }^{9}$ The results are rather mixed and sometimes they significantly change when different measures of the tax structure are used. In general, the statistical significance is higher when the tax structure is measured using implicit tax rates and holding the consumption tax base (ITR/C) constant. We summarize the main results showing the overall V-FD effects (when ITR/C is used) in Fig. 1.

\footnotetext{
9 Results available upon request.
} 


\section{a. REER}

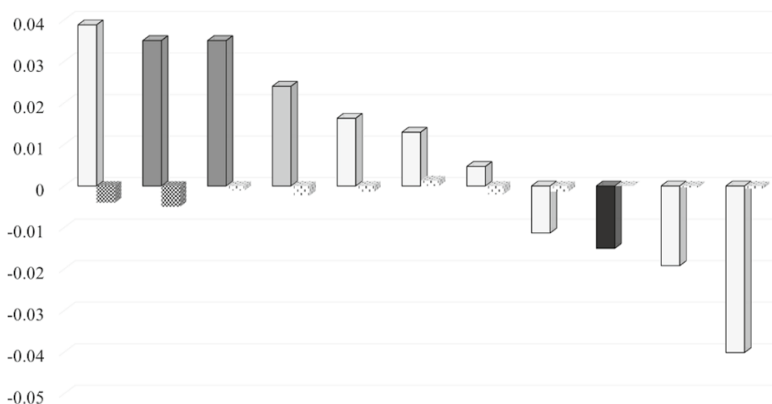

b. TOT

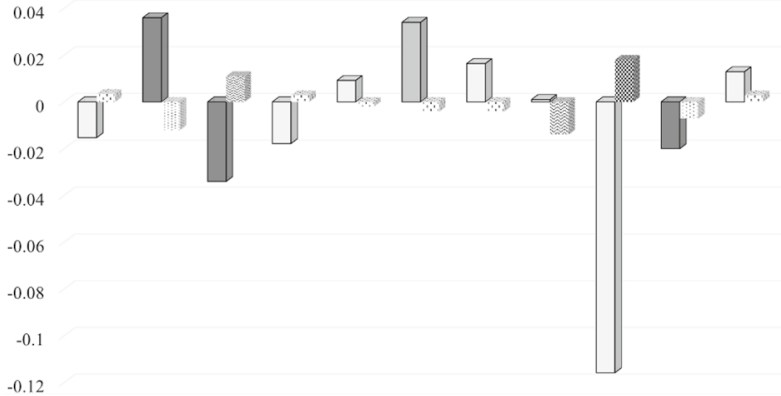

c. Net Exports

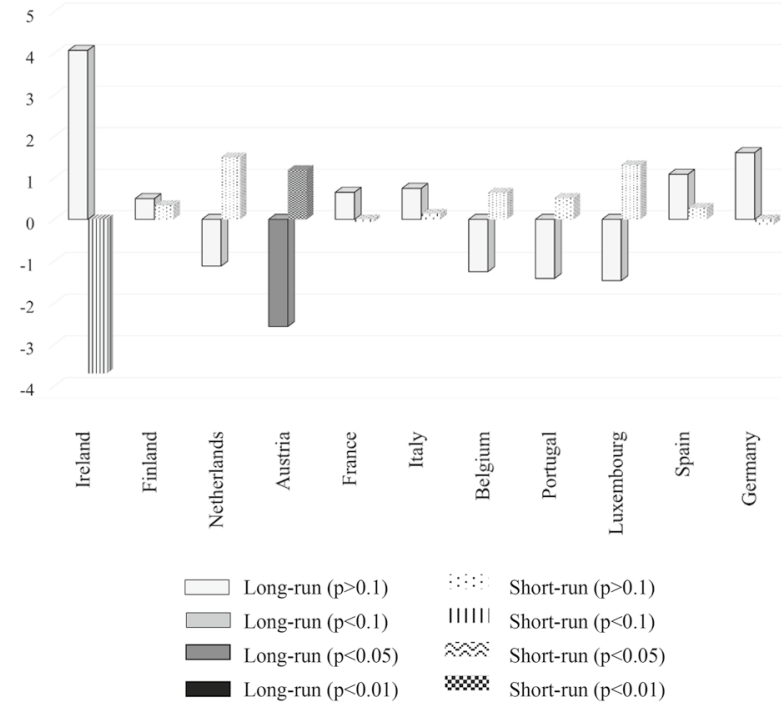

Fig. 1 Country-specific effects of fiscal devaluation. Tax variable: ITR/C. Note: Country-specific overall effects of fiscal devaluation, computed by averaging the impact of a $1 \%$ fiscal devaluation for each country and an equal revaluation by its trading partners. Tax wedges are measured by ITR/C. Shades emphasize statistical significance 
Table 10 Effects of fiscal devaluation for the sample of 19 EA countries (CMG estimates)

\begin{tabular}{|c|c|c|c|c|c|}
\hline & $\begin{array}{l}\text { Tax-GDP } \\
\text { (1) }\end{array}$ & $\begin{array}{l}\text { TR } \\
\text { (2) }\end{array}$ & $\begin{array}{l}\text { ITR } \\
(3)\end{array}$ & $\begin{array}{l}\text { ITR/C } \\
\text { (4) }\end{array}$ & $\begin{array}{l}\text { ITR/L } \\
\text { (5) }\end{array}$ \\
\hline \multicolumn{6}{|c|}{ i. Dependent: REER } \\
\hline \multicolumn{6}{|c|}{ Panel A: FD } \\
\hline Short run & $\begin{array}{l}-0.001 \\
(0.001)\end{array}$ & $\begin{array}{l}0.0002 \\
(0.0004)\end{array}$ & $\begin{array}{l}0.0003 \\
(0.001)\end{array}$ & $\begin{array}{l}0.0004 \\
(0.001)\end{array}$ & $\begin{array}{l}0.0004 \\
(0.001)\end{array}$ \\
\hline Long run & $\begin{array}{l}0.111 \\
(0.119)\end{array}$ & $\begin{array}{l}-0.007 \\
(0.007)\end{array}$ & $\begin{array}{l}-0.020 \\
(0.023)\end{array}$ & $\begin{array}{l}-0.009 \\
(0.006)\end{array}$ & $\begin{array}{l}-0.013 \\
(0.011)\end{array}$ \\
\hline \multicolumn{6}{|l|}{$\begin{array}{l}\text { Panel B: } \\
\quad F D \_T P\end{array}$} \\
\hline Short run & $\begin{array}{l}0.003 \\
(0.007)\end{array}$ & $\begin{array}{l}0.002 \\
(0.003)\end{array}$ & $\begin{array}{l}0.004 \\
(0.004)\end{array}$ & $\begin{array}{l}0.004 \\
(0.005)\end{array}$ & $\begin{array}{l}0.002 \\
(0.004)\end{array}$ \\
\hline Long run & $\begin{array}{l}0.331 \\
(0.537)\end{array}$ & $\begin{array}{c}-0.072 \\
(0.046)\end{array}$ & $\begin{array}{c}-0.148 \\
(0.127)\end{array}$ & $\begin{array}{l}-0.080 \\
(0.057)\end{array}$ & $\begin{array}{c}-0.063 \\
(0.069)\end{array}$ \\
\hline
\end{tabular}

Panel C:

Overall FD

Short run

$$
-0.002
$$

Long run

$$
-0.110
$$$$
\text { (0.211) }
$$

ii. Dependent: TOT

Panel A: FD

Short run

0.005
$(0.005)$

Long run

$$
-0.006
$$$$
\text { (0.013) }
$$

Panel B:

$$
\text { FD_TP }
$$

Short run

$$
0.045^{*}
$$$$
\text { (0.027) }
$$

Long run

$$
\begin{aligned}
& -0.090 \\
& (0.072)
\end{aligned}
$$

Panel C:

Overall FD

$\begin{array}{ll}\text { Short run } & -0.020 \\ & (0.013) \\ \text { Long run } & \begin{array}{l}0.042 \\ (0.032)\end{array}\end{array}$

iii. Dependent: Net exports

Panel A: FD

$\begin{array}{cl}\text { Short run } & 0.239 \\ & (0.703) \\ \text { Long run } & -1.180 \\ & (1.243)\end{array}$

Panel B:

$\begin{array}{llll}-0.001 & -0.002 & -0.002 & -0.001 \\ (0.002) & (0.002) & (0.002) & (0.002) \\ 0.033 & 0.064 & 0.036 & 0.025 \\ (0.020) & (0.053) & (0.027) & (0.030)\end{array}$

$\begin{array}{llll}0.002 & 0.004 & 0.004 & 0.004 \\ (0.001) & (0.003) & (0.002) & (0.003) \\ -0.0002 & -0.0096 & 0.0005 & 0.010 \\ (0.003) & (0.012) & (0.007) & (0.016)\end{array}$

$\begin{array}{llll}0.021 * * * & 0.026^{*} & 0.029 * & 0.026^{*} \\ (0.007) & (0.013) & (0.015) & (0.013) \\ 0.018 & 0.008 & -0.034 & -0.148 \\ (0.037) & (0.035) & (0.030) & (0.116)\end{array}$

\section{FD_TP}

Short run

$$
\begin{array}{r}
-0.057 \\
(1.531)
\end{array}
$$

\subsection{4}

(0.369)

0.022

$-0.011 *$

(0.006)

$-0.009$

$-0.009$

(0.020)

$-0.012^{*}$
$(0.007)$
0.017
$(0.016)$

$-0.011^{*}$ (0.006) 0.079 (0.065)

\begin{tabular}{llllll} 
Short run & -0.057 & -0.345 & -0.345 & -0.720 & -0.418 \\
& $(1.531)$ & $(0.642)$ & $(1.082)$ & $(0.906)$ & $(1.053)$ \\
\hline
\end{tabular}


Table 10 (continued)

\begin{tabular}{clllll}
\hline & $\begin{array}{l}\text { Tax-GDP } \\
(1)\end{array}$ & $\begin{array}{l}\text { TR } \\
(2)\end{array}$ & $\begin{array}{l}\text { ITR } \\
(3)\end{array}$ & $\begin{array}{l}\text { ITR/C } \\
(4)\end{array}$ & $\begin{array}{l}\text { ITR/L } \\
(5)\end{array}$ \\
\hline Long run & -5.662 & 3.518 & 0.297 & -5.250 & -2.235 \\
& $(5.340)$ & $(2.761)$ & $(2.292)$ & $(4.066)$ & $(3.388)$ \\
Panel C: & & & & & \\
$\begin{array}{c}\text { Overall FD } \\
\text { Short run }\end{array}$ & 0.148 & 0.209 & 0.183 & 0.602 & 0.125 \\
& $(0.734)$ & $(0.330)$ & $(0.479)$ & $(0.454)$ & $(0.484)$ \\
Long run & 2.241 & -2.064 & -0.167 & 1.797 & 0.983 \\
& $(2.390)$ & $(1.513)$ & $(1.351)$ & $(1.884)$ & $(1.498)$ \\
\hline
\end{tabular}

The table reports the effects of a fiscal devaluation for the sample of 19 EA countries. In $i$ and $i i$ the dependent variable is the REER and the TOT, respectively. iii reports the effects of a fiscal devaluation on net exports. Coefficients for fiscal devaluation are calculated by taking the difference between VAT and SSCs tax wedges computed using the measure specified in the first row. To account for the date of entry into the EA, in each estimation we control for the nominal effective exchange rate. The CMG estimates for the REER and the TOT are adjusted to a dynamic setting with the inclusion of one additional lag of all the variables. The following symbols indicate different significance levels: ***significant at $1 \%$; **significant at $5 \%$; *significant at $10 \%$. SE in parenthesis

Focusing on the short-run effects, we find that the REER depreciates (as the theory predicts) for most of the countries in the sample with the sole exception of Italy. In particular, a strongly statistically significant short-run correlation between the V-FD and the REER can be found only in Finland and Ireland. There is, instead, no clear evidence of a short-run depreciation for the TOT (the only country with a negative and statistically significant coefficient is Portugal), which in some cases appreciates (Austria, Germany, Ireland, Luxembourg and Netherlands) even if positive coefficients are statistically significant only for Luxembourg and Netherlands. As to the impact on net exports, for most of the countries we document a positive effect (which is statistically significant only in Austria), whereas a puzzling statistically significant negative effect is found for Ireland.

In general, the long-run effects go in the opposite direction of the short-run responses. Some notable exceptions are: Spain, for which (as for the short run) both relative prices depreciate in the long run with an ensuing trade balance improvement; Italy, which experiences a long-run REER appreciation and a net export increase; Germany, for which we find a REER depreciation and a TOT appreciation; and finally, Portugal and Luxembourg, with a long-run REER depreciation (the coefficient is strongly statistically significant for Luxembourg).

Finally, we performed a robustness check by considering all the countries that have joined the EA (EA19) after year 1999. To account for the dates of entry to the EA by different countries, we control in each estimation for the nominal effective exchange rate, which thus equals one starting from the entry date onward. Results reported in Table $10^{10}$ highlight that the results on the TOT and on net exports remain mostly unchanged, whereas they vanish entirely on the REER.

\footnotetext{
${ }^{10}$ For expositional purposes, we report the estimated coefficients only for fiscal devaluations. Full results available upon request.
} 


\section{Conclusions}

The theory suggests that a fiscal devaluation, by mimicking the effects of a nominal devaluation, should have a positive impact on a country's trade balance, at least in the short run, by making its exports more competitive with respect to those of the trading partners. The competitive effects that a fiscal devaluation could bring out should come mainly through relative price movements. Both a nominal and a fiscal devaluation affect the equilibrium allocations by changing the two main international relative prices. We have tested the theoretical hypothesis by looking at the direct effect of a revenue-neutral tax shift on the REER and the TOT, using data for EA countries.

Our results provide a weak support to the theoretical predictions (Farhi et al. 2014; Engler et al. 2017). We find a rather limited depreciation of both the TOT and the REER in the short run only in the most favourable scenario where a single country implements a V-FD while its trading partners simultaneously implement a fiscal revaluation. Moreover, the weak effects on relative prices are also reflected in the trade balance, for which we find negligible results in terms of both size and significance level. Net exports increase by no more than 0.3 per cent in the short run and the effects are not statistically significant in all the specifications reported.

Most importantly, our analysis shows that the responses to a fiscal devaluation are highly heterogeneous across countries. In fact, when the analysis is performed on each cross-section unit separately the results both on relative prices and on quantities are mixed, sometimes departing from expectations. This means that the effectiveness of structural reforms might be mainly driven by country-specific characteristics. Some of them are suggested by Ioannides and Pissarides (2015) such as the degree of competition in the product and factor markets, the state of the demand in the economy, as well as the country's institutional characteristics.

We may thus conclude that the potential of a V-FD should not be overemphasized since its effects are rather limited and can significantly differ across countries. We leave to future research the investigation of those economic characteristics which may explain why in some countries a fiscal devaluation seems to be more effective in improving external competitiveness.

Acknowledgements Open access funding provided by Università del Salento within the CRUI-CARE Agreement.

Open Access This article is licensed under a Creative Commons Attribution 4.0 International License, which permits use, sharing, adaptation, distribution and reproduction in any medium or format, as long as you give appropriate credit to the original author(s) and the source, provide a link to the Creative Commons licence, and indicate if changes were made. The images or other third party material in this article are included in the article's Creative Commons licence, unless indicated otherwise in a credit line to the material. If material is not included in the article's Creative Commons licence and your intended use is not permitted by statutory regulation or exceeds the permitted use, you will need to obtain permission directly from the copyright holder. To view a copy of this licence, visit http://creativecommons.org/licen ses/by/4.0/. 


\section{Appendix: Definition and sources of variables}

CPI deflated Real Effective Exchange Rate vis-à-vis the rest of EA countries (REER) (index, 2010=100); an increase in this indicator means a real appreciation. Source: European Commission, Price and Cost Competitiveness database.

Terms of Trade vis-à-vis the rest of EA countries (TOT) (index, 2010=100): computed as the ratio of export prices to import prices. An increase in this indicator means an appreciation. Source: authors' calculations based on Eurostat data.

Labour productivity per person $(Y)$ : (index, 2010=100): given by the difference between productivity in tradable and nontradable sectors. It is defined as gross value added over the number of employees. Tradable sectors include industry (without construction) and agriculture, forestry and fishing. Nontradable are all the other sectors. Source: authors' calculations based on Eurostat data.

Government spending (G) (as a percentage of GDP), computed as the sum of government consumption and government investment. Source: Eurostat, quarterly non-financial accounts for general government.

Total revenues (T) (as a percentage of GDP). Source: Eurostat, quarterly nonfinancial accounts for general government.

Long-term real interest rate (I) (per cent): given by central government bond yields on the secondary market, gross of tax, with a residual maturity of around 10 years (Maastricht Treaty EMU convergence criterion bond yields). To get real variables we subtract inflation rate as measured by the percentage change in CPI. Source: Eurostat.

Net Exports (as a percentage of GDP): exports minus imports of goods and services. Source Eurostat.

GDP growth rate (GDP) (in percentage): GDP change from the previous period. Source: Eurostat.

Dependency ratio (DEP) (in percentage): given by the share of the population aged 65 and above in population aged 15-64. Source: Eurostat

Unemployment rate (UR) (in percentage): total unemployment rate in percentage of labour force. Source: OECD Labour market statistics.

General government balance (GGbal) (in percentage of GDP), positive for a surplus. Source: Eurostat: General government, net lending (+)/net borrowing (-).

Revenues other than that from VAT and SSCs (REV) (in percentage of GDP): given by total general government revenue minus actual VAT and SSCs revenues. Source: Eurostat.

Implicit tax rates $\left(\mathrm{VAT}_{\mathrm{ITR}}\right.$ and $\mathrm{SSC}_{\mathrm{ITR}}$ ) are computed using the methodology suggested by European Commission (2016). The following list provides the tax revenue and national accounts data used. Using the European Commission's codes, variables used are:

- $d 211$, rec: VAT, receivable;

- d611 Employers' actual social contributions;

- $d 613$ Households' actual social contributions; 
Table 11 Descriptive statistics

\begin{tabular}{|c|c|c|c|c|c|c|}
\hline Variables & Description & Obs. & Mean & SD & Min & Max \\
\hline REER & Log of CPI deflated REER & 836 & 4.61 & 0.03 & 4.51 & 4.68 \\
\hline TOT & Log of the terms of trade & 836 & 4.61 & 0.03 & 4.52 & 4.73 \\
\hline $\mathrm{Y}$ & $\begin{array}{l}\text { Productivity differential between tradables and } \\
\text { nontradables }\end{array}$ & 836 & 350.26 & 93.49 & 73.37 & 943.77 \\
\hline I & Long-term real interest rate & 825 & 3.17 & 1.80 & -1.52 & 12.30 \\
\hline G & Government spending over GDP & 836 & 23.25 & 3.33 & 13.06 & 32.28 \\
\hline $\mathrm{T}$ & Total revenues over GDP & 836 & 44.63 & 6.52 & 22.68 & 59.50 \\
\hline Net Exports & Net exports & 836 & 5.58 & 9.86 & -12.70 & 38.20 \\
\hline GDP & GDP growth rate & 825 & 1.10 & 4.99 & -12.96 & 30.10 \\
\hline DEP & Dependency ratio & 790 & 24.96 & 4.39 & 12.67 & 34.56 \\
\hline UR & Unemployment rate & 836 & 8.26 & 4.03 & 1.73 & 26.93 \\
\hline GGbal & General government balance over GDP & 836 & -2.18 & 4.89 & -41.76 & 11.00 \\
\hline REV & Revenues other than VAT and SSCs & 836 & 30.78 & 4.94 & 15.05 & 42.59 \\
\hline VAT $_{\text {GDP }}$ & VAT revenues over GDP & 836 & 6.86 & 1.09 & 2.09 & 9.42 \\
\hline $\mathrm{SSC}_{\mathrm{GDP}}$ & SSCs revenues over GDP & 836 & 7.00 & 2.59 & 2.21 & 12.34 \\
\hline $\mathrm{VAT}_{\mathrm{GDP}(\mathrm{TP})}$ & $\begin{array}{l}\text { VAT revenues over GDP (trading partners' } \\
\text { average) }\end{array}$ & 836 & 6.62 & 0.23 & 4.94 & 7.18 \\
\hline $\mathrm{SSC}_{\mathrm{GDP}(\mathrm{TP})}$ & $\begin{array}{l}\text { SSCs revenues over GDP(trading partners' } \\
\text { average) }\end{array}$ & 836 & 7.47 & 0.37 & 6.48 & 8.38 \\
\hline $\mathrm{VAT}_{\mathrm{TR}}$ & VAT tax ratio & 836 & 15.56 & 2.82 & 5.89 & 27.92 \\
\hline $\mathrm{SSC}_{\mathrm{TR}}$ & SSCs tax ratio & 836 & 15.49 & 5.08 & 5.54 & 27.12 \\
\hline $\mathrm{VAT}_{\mathrm{TR}(\mathrm{TP})}$ & VAT tax ratio (trading partners' average) & 836 & 14.83 & 0.67 & 12.01 & 16.88 \\
\hline $\mathrm{SSC}_{\mathrm{TR}(\mathrm{TP})}$ & SSCs tax ratio (trading partners' average) & 836 & 16.72 & 0.72 & 15.15 & 19.16 \\
\hline VAT $_{\text {ITR }}$ & VAT implicit tax rate & 836 & 13.84 & 3.19 & 3.79 & 27.85 \\
\hline $\mathrm{SSC}_{\mathrm{ITR}}$ & SSCs implicit tax rate & 836 & 13.12 & 4.79 & 5.16 & 22.75 \\
\hline $\mathrm{VAT}_{\mathrm{ITR}(\mathrm{TP})}$ & $\begin{array}{l}\text { VAT implicit tax rate (trading partners' aver- } \\
\text { age) }\end{array}$ & 836 & 12.43 & 0.59 & 9.11 & 13.95 \\
\hline $\mathrm{SSC}_{\mathrm{ITR}(\mathrm{TP})}$ & $\begin{array}{l}\text { SSCs implicit tax rate (trading partners' aver- } \\
\text { age) }\end{array}$ & 836 & 13.99 & 0.57 & 12.58 & 15.78 \\
\hline $\mathrm{VAT}_{\mathrm{ITR}} / \mathrm{L}$ & VAT ITR over labour base & 836 & 12.96 & 2.16 & 3.66 & 20.27 \\
\hline $\mathrm{VAT}_{\text {ITR }} / \mathrm{L}_{(\mathrm{TP})}$ & $\begin{array}{l}\text { VAT ITR over labour base (trading partners' } \\
\text { average) }\end{array}$ & 836 & 12.41 & 0.55 & 9.16 & 13.89 \\
\hline $\mathrm{SSC}_{\mathrm{ITR}} / \mathrm{C}$ & SSC ITR over consumption base & 836 & 13.72 & 4.46 & 5.16 & 22.48 \\
\hline $\mathrm{SSC}_{\mathrm{ITR}} / \mathrm{C}_{(\mathrm{TP})}$ & $\begin{array}{l}\text { SSC ITR over consumption base (trading } \\
\text { partners' average) }\end{array}$ & 836 & 14.02 & 0.75 & 11.92 & 16.31 \\
\hline
\end{tabular}

The 11 countries included in the data set are: Austria, Belgium, Finland, France, Germany, Ireland, Italy, Luxembourg, Netherlands, Portugal and Spain. The observation period is 1999Q1-2017Q4

- p31_s14: Final consumption expenditure of households.

- coel: Compensation of employees;

- ES and EE are, respectively, self-employment and dependent employment (thousands of persons).

- $W$ : wages and salaries. 
Implicit tax rate for VAT is computed as follows:

$$
\mathrm{VAT}_{\text {ITR }}=\frac{d 211, \mathrm{rec}}{p 31 \_s 14} .
$$

To obtain implicit tax rates on SSCs we first compute the wage bill (WSE) given by:WSE $=\frac{\mathrm{ES} * \mathrm{~W}}{\mathrm{EE}}$, and thus implicit tax rate for SSCs is:

$$
\mathrm{SSC}_{\mathrm{ITR}}=\frac{d 611+d 613}{\text { coel }+\mathrm{WSE}} .
$$

Tax ratios $\left(\mathrm{VAT}_{\mathrm{TR}}\right.$ and $\left.\mathrm{SSC}_{\mathrm{TR}}\right)$ are obtained by dividing tax revenues on VAT and SSCs, respectively, by total revenues.

Tax to GDP ratios $\left(\mathrm{VAT}_{\mathrm{GDP}}\right.$ and $\mathrm{SSC}_{\mathrm{GDP}}$ ) are obtained by dividing tax revenues on VAT and SSCs, respectively, by GDP.

Tax revenues data (in million units of national currencies) comes from Eurostat, Quarterly non-financial accounts for general governments (data on SSCs for Italy comes from Istat). National accounts data (in million units of national currencies) from Eurostat, Quarterly National Accounts database. Table 11 reports descriptive statistics of key variables.

\section{References}

Alesina, A., \& Perotti, R. (1995). Fiscal expansions and adjustments in OECD countries. Economic policy, 10(21), 205-248.

Alworth, J., \& Arachi, G. (2010). Taxation policy in EMU. In M. Buti, S. Deroose, V. Gaspar, \& J. Nogueria Martins (Eds.), Euro-the first decade (pp. 557-596). Cambridge: Cambridge University Press.

Annicchiarico, B., Di Dio, F., \& Felici, F. (2015). Fiscal devaluation scenarios: A quantitative assessment for the Italian economy. Open Economies review, 26(4), 731-785.

Arachi, G., Bucci, V., \& Casarico, A. (2015). Tax structure and macroeconomic performance. International Tax and Public Finance, 22(4), 635-662.

Arnold, J., Brys, B., Heady, C., Johansson, A., Schwellnus, C., \& Vartia, L. (2011). Tax policy for economic recovery and growth. The Economic Journal, 121, F59-F80.

Auerbach, A., Devereux, M.P., Keen, M. \& Vella, J. (2017). Destination-based cash flow taxation. Oxford University Centre for Business Taxation Working Paper No. 17-01.

Balassa, B. (1964). The purchasing-power parity doctrine: a reappraisal. Journal of Political Economy, 72(6), 584-596.

Bénétrix, A. S., \& Lane, P. R. (2013). Fiscal shocks and the real exchange rate. International Journal of Central Banking, 9(3), 6-37.

Bleaney, M., Gemmell, N., \& Kneller, R. (2001). Testing the endogenous growth model: Public expenditure, taxation and growth over the long run. Canadian Journal of Economics, 34, 36-57.

Calmfors, L. (1993). Lessons from the macroeconomic experience of Sweden. European Journal of Political Economy, 9(1), 25-72.

Calmfors, L. (1998). Macroeconomic policy, wage setting, and employment-what difference does the EMU make? Oxford Review of Economic Policy, 14, 125-151.

Candelon, B., Kool, C., Raabe, K., \& van Veen, T. (2007). Long run real exchange rate determinants: Evidence from eight new EU member states 1993-2003. Journal of Comparative Economics, 35, 87-107.

Chinn, M. D., \& Prasad, E. S. (2003). Medium-term determinants of current accounts in industrial and developing countries: an empirical exploration. Journal of International Economics, 59(1), 47-76. 
Chudik, A., \& Pesaran, M. H. (2015). Common correlated effects estimation of heterogeneous dynamic panel data models with weakly exogenous regressors. Journal of Econometrics, 188(2), 393-420.

Chudik, A., Pesaran, M. H., \& Tosetti, E. (2011). Weak and strong cross section dependence and estimation of large panels. Econometrics Journal, 14(1), C45-C90.

Corsetti, G., Dedola, L., \& Leduc, S. (2006). Productivity, external balance and exchange rates: Evidence on the transmission mechanism among G7 countries. In NBER International Seminar on Macroeconomics 2006, (pp. 117-194). Chicago: University of Chicago Press.

Corsetti, C., Martin, P., \& Pesenti, P. (2007). Productivity, terms of trade and the home market effect. Journal of International Economics, 73, 99-127.

De Castro, F., \& Garrote, D. (2015). The effects of fiscal shocks on the exchange rate in the EMU and differences with the USA. Empirical Economics, 49(4), 1341-1365.

De Mooij, R., \& Keen, M. (2013). Fiscal devaluation and fiscal consolidation: The VAT in troubled times. In A. Alesina \& F. Giavazzi (Eds.), Fiscal policy after the financial crisis. Chicago: University of Chicago Press.

Eberhardt, M., \& Presbitero, A. F. (2015). Public and growth: Heterogeneity and non-linearity. Journal of International Economics, 97(1), 45-58.

Égert, B., Lommatzsch, K., \& Larhèche-Révil, A. (2006). Real exchange rate in small open OECD and transition economies: comparing apples with oranges. Journal of Banking \& Finance, 30, 3393-3406.

Enders, Z., Müller, G. J., \& Scholl, A. (2011). How do fiscal and technology shocks affect real exchange rates? New evidence for the U.S. Journal of International Economics, 83, 53-69.

Engler, P., Ganelli, G., Tervala, J., \& Voigts, S. (2017). Fiscal devaluation in a monetary union. IMF Economic Review, 65(2), 241-272.

Engler, P., Pasch, S., \& Tervala, J. (2018). Third country effects of fiscal devaluations. Economics Letters, 163, 13-16.

Erceg, C. J., Prestipino, A., \& Raffo, A. (2018). The macroeconomic effects of trade policy. FRB International Finance Discussion Paper (1242).

European Commission. (2013). Taxation trends in the European Union. Brussels: Publications Office of the European Union.

European Commission. (2016). Taxation trends in the European Union. Brussels: Publications Office of the European Union.

Farhi, E., Gopinath, G., \& Itskhoki, O. (2014). Fiscal devaluation. Review of Economic Studies, 81(2), $725-760$.

Freund, C., \& Gagnon, J. (2017). Effects of consumption taxes on real exchange rates and trade balances. Peterson Institute for International Economics Working Paper (17-5).

Galstyan, V., \& Lane, P. R. (2009). The composition of government spending and the real exchange rate. Journal of Money, Credit and Banking, 41(6), 1233-1249.

Ghironi, F., \& Melitz, M. (2005). International Trade and Macroeconomics dynamics with heterogeneous firms. Quarterly Journal of Economics, 120(3), 865-915.

Gomes, S., Jacquinot, P., \& Pisani, M. (2016). Fiscal devaluation in the euro area: A model-based analysis. Economic Modelling, 52, 58-70.

Griffoli, T. M., Meyer, C., Natal, J. M., \& Zanetti, A. (2015). Determinants of the Swiss franc real exchange rate. Swiss Journal of Economics and Statistics, 151(4), 299-331.

Holzner, M., Tkalec, M., Vizek, M., \& Vukšić, G. (2018). Fiscal devaluations: Evidence using bilateral trade balance data. Review of World Economics, 154(2), 247-275.

Im, K. S., Pesaran, H. M., \& Shin, Y. (2003). Testing for unit roots in heterogeneous panels. Journal of Econometrics, 115, 53-74.

Ioannides, Y. M., \& Pissarides, C. A. (2015). Is the Greek crisis one of supply or demand? Brookings Papers on Economic Activity, (Fall 2015), 349-383.

Kangur, A. (2018). Competitiveness and wage bargaining reform in Italy. IMF Working Paper 18/61.

Keen, M., \& Syed, M. (2006). Domestic taxes and international trade: Some evidence. IMF Working Paper 06/47. Washington, DC: International Monetary Fund.

Keynes, J. M. (1931). Addendum to: Great Britain. Committee on Finance and Industry Report [Macmillan Report] (London: His Majesty's Stationery Office, 1931) 190-209. Reprinted in Donald Moggridge, The Collected Writings of John Maynard Keynes, Vol. 20 (London: Macmillan and Cambridge: Cambridge Press for the Royal Economic Society, 1981), 283-309.

Koske, I. (2013). Fiscal devaluation-can it help to boost competitiveness? (OECD Department Working Papers, No. 1089). Paris, France: OECD Publishing. https://doi.org/10.1787/5k3z2dckn2bw-en. 
Lane, P., \& Perotti, R. (1998). The trade balance and fiscal policy in the OECD. European Economic Review, 42, 887-895.

Lane, P., \& Perotti, R. (2003). The importance of composition of fiscal policy: evidence from different exchange rate regimes. Journal of Public Economics, 87, 2253-2279.

Maddala, G. S., \& Wu, S. (1999). A comparative study of unit root tests with panel data and a new simple test. Oxford Bulletin of Economics and Statistics, 61(S1), 631-652.

Mendoza, E. G., Razin, A., \& Tesar, L. L. (1994). Effective tax rates in macroeconomics: Cross-country estimates of tax rates on factor incomes and consumption. Journal of Monetary Economics, 34, 297-323.

Monacelli, T., \& Perotti, R. (2008). Openness and the sectoral effects of fiscal policy. Journal of the European Economic Association, 6(2-3), 395-403.

Obstfeld, M., \& Rogoff, K. (1998). Foundations of international macroeconomics. Cambridge, MA: MIT Press.

Obstfeld, M., \& Rogoff, K. (2000). New directions for stochastic open economy models. Journal of International Economics, 50(1), 117-153.

Pesaran, M. H. (2004). General diagnostic tests for cross section dependence in panels. CESifo Working Paper Series No. 1229.

Pesaran, M. H. (2006). Estimation and inference in large heterogeneous panels with a multifactor error structure. Econometrica, 74(4), 967-1012.

Pesaran, M. H. (2007). A simple panel unit root test in the presence of cross-section dependence. Journal of Applied Econometrics, 22, 265-312.

Pesaran, M. H. (2015). Testing weak cross-sectional dependence in large panels. Econometric Reviews, 34(6-10), 1089-1117.

Pesaran, M. H., \& Tosetti, E. (2011). Large panels with common factors and spatial correlations. Journal of Econometrics, 161(2), 182-202.

Ricci, L. A., Milesi-Ferretti, G. M., \& Lee, J. (2013). Real exchange rate and fundamentals: A crosscountry perspective. Journal of Money, Credit and Banking, 45(5), 845-865.

Samuelson, P. A. (1964). Theoretical notes on trade problems. The Review of Economics and Statistics, 46(2), 145-154.

Stockhammer, E., \& Sotiropoulos, D. P. (2014). Rebalancing the Euro area: The costs of internal devaluation. Review of Political Economy, 26(2), 210-233.

Tkalec, M., Vizek, M., \& Vukšić, G. (2019). Fiscal devaluation and real exchange rates in the Euro area: Some econometric insights. Review of International Economics, 27(2), 694-710.

Xing, J. (2012). Does tax structure affect economic growth? Empirical evidence from OECD countries. Economics Letters, 117(1), 379-382.

Publisher's Note Springer Nature remains neutral with regard to jurisdictional claims in published maps and institutional affiliations. 